\title{
The digestive morphophysiology of wild, free-living, giraffes
}

\author{
G Mitchell $^{1,2}$, DG Roberts ${ }^{2} \&$ SJ van Sittert $^{2}$
}

Department of Zoology and Physiology, University of Wyoming, Laramie, WY 82071, USA ${ }^{1}$, and Centre for Veterinary Wildlife Studies, Faculty of Veterinary Science, University of Pretoria, Onderstepoort, South Africa ${ }^{2}$. email : mitchg@uwyo.edu.,africatvet@africat.org., sybrand@yahoo.com.

Corresponding author: G Mitchell

\begin{abstract}
We have measured rumen-complex (rumen, reticulum, omasum, abomasum) and intestine (small and large combined) mass in 32 wild giraffes of both sexes with body masses ranging from $289-1441 \mathrm{~kg}$, and parotid gland mass, tongue length and mass, masseter and mandible mass in 9 other giraffes ranging in body mass from 181 to $1396 \mathrm{~kg}$. We have estimated metabolic and energy production rates, feed intake and home range size. Interspecific analysis of mature ruminants show that components of the digestive system increase linearly $\left(\mathrm{Mb}^{1}\right)$ or positively allometric $\left(\mathrm{Mb}^{>1}\right)$ with body mass while variables associated with feed intake scale with metabolic rate $\left(\mathrm{Mb}^{75}\right)$. Conversely, in giraffes ontogenetic increases in rumen-complex mass were negatively allometric $\left(\mathrm{Mb}^{<1}\right)$, and increases in intestine mass, parotid gland mass, masseter mass, and mandible mass were isometric $\left(\mathrm{Mb}^{1}\right)$. The relative masseter muscle mass $(0.14 \%$ of $\mathrm{Mb})$ and the relative parotid mass $(0.03 \%$ of $\mathrm{Mb})$ are smaller than in other ruminants. Increases in tongue length scale with head length ${ }^{0.72}$ and $\mathrm{Mb}^{.32}$ and tongue mass with $\mathrm{Mb}^{69}$. Absolute mass of the gastrointestinal tract increased throughout growth but its relative mass declined from $20 \%$ to $15 \%$ of $\mathrm{Mb}$. Rumen-complex fermentation provides ca43\% of daily energy needs, large intestine fermentation $24 \%$ and $33 \%$ by digestion of soluble carbohydrates, proteins, and lipids. Dry matter intake $(\mathrm{kg})$ was $2.4 \%$ of body mass in juveniles and $1.6 \%$ in adults. Energy requirements increased from $35 \mathrm{Mj} /$ day to $190 \mathrm{Mj} /$ day. Browse production rate sustains a core home range of $2.2-11.8 \mathrm{~km}^{2}$.
\end{abstract}

Key Words: Giraffe, Digestion, Anatomy, Physiology, Ecology 


\section{Introduction}

While much is known about the diets of wild giraffes (e.g. Hall-Martin and Basson 1975; Pellew 1984A) and their feeding ecology (Leuthold and Leuthold 1972; Pellew 1983A, B; du Toit 1990A, B, C; Young and Isbell 1991; Woolnough and du Toit 2001; Cameron and du Toit 2007), how and where the browse they eat is processed to provide the energy and nutrients they need is relatively unknown. The anatomy of their mouths and adnexal structures has been described in detail by Owen (1838), Joly \& Lavocat (1846), and Perez et al (2012), as has the relevance of the shape of their maxilla (Solounias \& Moelleken, 1993). Systematic analysis of the structure and development of their brachydont, selenodont teeth and their dental formula has been described by Singer and Boné (1960) and Hall-Martin (1976), but no analysis of their role in the acquisition of browse has been done. Anecdotally Hamilton (1978) suggested that the bilobed lower canine functioned to strip browse, and as the ridge-basin structure of molars in southern African browsers is highly conserved we assume that their function follows the typical pattern as described by Archer \& Sanson (2002): the selenodont ridges act to shear browse and the basins crush it. There have been sporadic measurements of salivary gland mass (Robbins et al, 1995; Hofmann et al, 2008) but no systematic analysis of their ontogeny. Masseter muscle mass has been reported in a single captive giraffe by Clauss et al (2008) and by us in wild giraffes in the context of the anatomy of their head and skull and not digestion (Mitchell et al, 2013B). Similarly, we have reported mandible mass, and tongue length and mass (Mitchell et al, 2013B).

There has also not been a systematic analysis of the ontogeny of their gastrointestinal tract. Studies on ruminants in general have concluded that the size of the gastrointestinal tract should increase linearly with increases in body mass (Demment, 1982; Demment and van Soest, 1985; Ginnett \& Demment, 1997). Ginnett \& Demment (1997) qualitatively confirmed this conclusion in giraffes by studying the eating habits of males and females. Males eat more in a shorter time than females and as males are larger than females they must also have a larger rumen. Clauss et al. (2003A) suggested that the most important function of the rumen is to delay the passage of ingesta and prolong digestion time. Delayed passage implies a slowly emptying rumen which inhibits intake, so its absolute and relative mass should increase linearly with body mass to compensate for both intake limitation and for the greater absolute energy needs that large size demands. In a seminal but controversial study Hofmann (1989) classified giraffe as concentrate selectors or obligatory browsers and, therefore, the structure of their gastrointestinal tract should be different to that of grazers. Browsers have relatively small rumens (Giesecke \& van Gylswyk, 1975), a relationship confirmed by a meta-analysis of published data (Clauss et al, 2003B), and relatively big intestines (Hofmann, 1989). However, no quantitative data exists to support either one or the other of these possibilities, or to describe changes in the mass of the major components of the gastrointestinal tract in wild giraffes during growth. 
With some exceptions (Weckerly, 2010; Luna et al, 2012) many of the data used to describe the gastrointestinal morphophysiology of ruminants have been derived from interspecific studies of mature animals with different body masses. In the study reported here measurements of gastrointestinal dimensions in 32 wild giraffes of body mass ranging from $289-1441 \mathrm{~kg}$ were used to generate intraspecific, ontogenic, allometric equations to describe changes in their gastrointestinal morphology during growth and to provide a basis for an analysis of their digestive physiology. In 9 other giraffes of body mass ranging from 181 to $1396 \mathrm{~kg}$ the growth patterns of the parotid glands, masseter muscles, mandible and tongue have been analyzed. Our data have allowed us to estimate giraffe energy requirements, feed intake and the home range size needed to support their metabolism. The hypothesis on which the study was based is that giraffe digestive morphophysiology will be uniquely adapted and different to that of grazing ruminants as predicted by Hofmann (1989).

\section{Method}

Body mass (Mb, $\mathrm{kg}$ ). In total, body mass was measured in 30 female giraffes (Mb range 147 to 1029 $\mathrm{kg}$ ) and 30 male giraffes $(\mathrm{Mb}$ range $=181$ to $1441 \mathrm{~kg}$ ) that had been culled as part of the Bubye Conservancy management program in Zimbabwe. Of these, 32 constituted the study group for analysis of gastrointestinal morphology and 9 for analysis of the masticatory apparatus. At the time of cull giraffes were browsing/standing quietly. $22(13+9)$ of the giraffe were culled at the start of the wet season (November) and 19 at the end of the wet season (April). Giraffe were culled opportunistically between 0600 and 1700 hours. The content of their gastrointestinal tract was natural browse existing at the time of cull. Two methods were used to determine body mass to take into account loss of tissue during dissection and variation with season. First, before any dissection took place length $(\mathrm{L})$ and girth $(\mathrm{G})$ in metres were measured and body mass $(\mathrm{kg})$ calculated from regression equations developed for giraffes by Hall-Martin (1977). These equations are:

Males: $26.117 * L^{*} G^{2}+33.945$

Females: $25.400 * L^{*} G^{2}+66.109$

where $\mathrm{L}$ (metres) is total length measured from the tip of the nose to the tip of the tail and G (metres) the girth of the thorax measured immediately caudal to the front legs. Secondly, the giraffes were weighed piecemeal as described previously (e.g. Mitchell et al, 2009). The body mass used in our analyses was the mean of the mass calculated from the relevant gender specific equation and the mass obtained by piecemeal weighing. In males the relationship between piecemeal and calculated $\mathrm{Mb}$ is Calculated $\mathrm{Mb}=0.86 *$ PiecemealMb^1.03 $\left(\mathrm{CI}_{\mathrm{exp}}=.97-1.09 ; \mathrm{R}^{2}=.9754\right)$, and in females $\mathrm{CMb}=1.39 * \mathrm{PMb}^{\wedge} .96\left(\mathrm{CI}_{\exp }=.90-1.02 ; \mathrm{R}^{2}=.9792\right)$. Before piecemeal weighing both parotid salivary 
glands, both masseter muscles, and the tongue were removed by dissection. The mandibles were cleaned by boiling. All components were weighed to an accuracy of 2 gram using an electronic scale, and in the case of tongue length, measured to an accuracy of $1 \mathrm{~cm}$.

Rumen-complex and Intestine mass (kg). We measured total forestomach mass (rumen, reticulum, omasum and abomasum including their contents = rumen-complex) and total intestine mass (small and large intestines combined including their contents= intestine). No attempt was made to separate mesenteries and/or adnexal adipose tissue or to weigh contents separately from organ tissue.

Measurements of total gastrointestinal mass (kg; rumen-complex + intestines) were obtained from 30 giraffes (15 males Mb range 455-1441 kg), and 15 females (Mb range $414-1029 \mathrm{~kg}$ ). Rumencomplex mass was recorded in 12 males $(\mathrm{Mb}=455-1282 \mathrm{~kg})$ and in 9 females $(\mathrm{Mb}=399-992 \mathrm{~kg})$. Combined intestinal mass was recorded in 13 males $(\mathrm{Mb}=289-1282 \mathrm{~kg})$ and in 8 females $(\mathrm{Mb}=414$ $-992 \mathrm{~kg})$. Both measurements were recorded in 12 males $(\mathrm{Mb}=455-1282 \mathrm{~kg})$ and in 8 females $(\mathrm{Mb}=414-992 \mathrm{~kg})$. For the comparison with grazing ruminants we used the mass of the rumenreticulum contents from 41 wild ruminants obtained from six species by Giesecke \& van Gylswyk (1975), Demment (1982) and Maloiy et al (1982). The six species analyzed were those classified as grazers by Hofmann (1989).

Intestine length (metres). We did not measure intestine lengths but in the historical literature intestine length has been reported in 14 giraffes ( 7 female and 7 male), of age 2 months to 21 years and 3 months (Table 1B). More recently Perez et al. (2009) measured intestinal lengths in a two-year-old male weighing $754 \mathrm{~kg}$ and a 17 year-old female weighing $800 \mathrm{~kg}$ (Table 1B). These data were used to develop allometric equations to describe the growth of intestinal length with age. One other measured length is known in a giraffe of known body mass $(545 \mathrm{~kg}$ ) and it was reported to be 280 feet or 85 metres (Goetz and Budtz-Olsen, 1955). This length: body mass relationship is not consistent with other data and was probably an error of reporting, so it has not been included in the analysis. The correct length was most probably 180 feet $=54$ metres. Intestine length of giraffes was also compared to the lengths found in 47 animals from 8 species of wild African grazing ruminants of body mass 29$240 \mathrm{~kg}$ and 50 animals from 8species of wild African browsing/intermediate feeder ruminants of body mass 8.5-411 kg (Table 1C; Woodall and Skinner, 1993).

Energy balance. Three measures of energy consumption in a mammal are basal metabolic rate (BMR), resting metabolic rate (RMR) and Field metabolic Rate (FMR). The best measure of the minimum daily energy consumption is FMR. The main determinant of FMR in a ruminant is body mass as described by Nagy (2005; kj/day) and it was estimated for the giraffes in this study by an allometric equation derived from data for FMR in ruminants (Calder 1996; Nagy 1994 and 2005; 
McNab 2002) and compared to estimates obtained empirically by Pellew in giraffes (Pellew, 1984A). Energy is produced by a combination of fermentation of the cell wall of browse eaten and fermentation and digestion of browse cell contents. The main product of fermentation is volatile fatty acids (VFA). The main sites of fermentation are the rumen and large intestine. Fermentation in the abomasum and small intestine of giraffes is negligible accounting for 5.5\% and 3.4\% respectively of total VFA produced (Clemens \& Maloiy, 1983). The energy content of VFA varies according to the ratio of the acetic: propionic: butyric acid mixture present but is remarkably constant varying by less than $5 \%$ across ruminants. Its average value in 20 species of ruminant was found to be $1125 \pm 50 \mathrm{kj} / \mathrm{moleVFA}$ (Gordon and Illius,1994). In eight browsers it was $1109 \pm 49 \mathrm{kj} / \mathrm{mole}$, in eight grazers $1151 \pm 47$, and in four intermediate feeders $1110 \pm 51$. The average value in six giraffes was $1095 \mathrm{kj} / \mathrm{mole}$ (Maloiy et al, 1982). The rate at which VFA's are produced in giraffes is $4.06 \mathrm{moles} / \mathrm{kg}$ Dry Matter/day (Maloiy et al, 1982). The concentration of Dry Matter (DM) in the rumen-complex (including the abomasum), and hindgut (caecum, proximal and distal colon) in giraffes has been measured by Clemens and Maloiy (1983) to be on average $13.5 \pm 0.5 \%$ and $18.5 \pm 2.0 \%$ of mass respectively. The amount of energy (kj/day) produced by fermentation in the rumen-complex and hind gut of the giraffes in this study was calculated from fermentation data of Maloiy et al. (1982) and Clemens \& Maloiy (1983) and from the masses of the rumen-complex and intestine measured in our study. In calculating rumen-complex fermentation rate we took into account that the mass of the rumen-complex included tissue mass which contributes $13.1 \pm 2.0 \%$ to rumen mass (Giesecke and van Gylswyk, 1975). The energy (kj/day) extracted by other digestive processes was calculated by subtracting the energy produced by fermentation from the total energy required to meet FMR.

Feed intake (kg Dry Matter/day). The minimum amount of browse that must be consumed by giraffes to meet FMR can be calculated by dividing the calculated FMR (kj/day) for each giraffe by the metabolizable energy content of browse (Nagy, 1987). Two analyses of metabolizable energy (ME) content of browse eaten by wild giraffe have been made, one in the Serengeti by Pellew (1984A) and the other in the Timbavati Nature Reserve by Hall-Martin \& Basson (1975). HallMartin \& Basson made 12 monthly measurements of browse constituents. Metabolizable energy calculated from the dietary constituents measured and using standard equations was $8.3 \mathrm{kj} / \mathrm{g}$ in

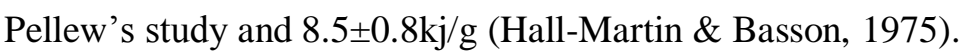

Home range (HR) size $\left(\mathrm{km}^{2}\right)$. The primary determinant of HR size is the productivity of the browse which in turn is determined by climate and rainfall (Leuthold and Leuthold 1978; Pellew 1983A). The only measurement so far made of the production rate of the browse eaten by giraffes was made in the Serengeti (Pellew, 1983A). It was found to be $c a 7000 \mathrm{kgDM} /$ hectare/annum which is equivalent to 1866 watts. $\mathrm{km}^{-2}$. The size of the HR of giraffes varies between a minimum (the core HR; du Toit 1990C) set by the relationship between food requirements and the productivity of browse, and a 
maximum which is set by the long distance meanderings of a giraffe outside the core area. The minimum HR size $\left(\mathrm{km}^{2}\right)$ was calculated by dividing FMR (watts) by browse production rate $\left(\right.$ watts. $\left.\mathrm{km}^{2}\right)$. The minimum feed intake needed to meet FMR from the HR $\left(\mathrm{kg} \cdot \mathrm{day}^{-1} \cdot \mathrm{km}^{-2}\right)$ was calculated by dividing feed intake by minimum HR.

Data analysis. The relationships between body dimensions and organ dimensions/functions during growth can be described through power functions of the form $y=a M^{b}$, where $a$ is the intercept, $M$ body mass, and $b$ the slope. The data were $\log$ transformed and used to develop equations with body mass as the covariate. In the analyses that follow Mb is kilograms $(\mathrm{kg})$ in all cases. No gender differences between giraffes of equivalent body masses were found for any of the variables and the data were combined for further analyses. Where two or more published equations for a variable exist each equation was used to generate values for the variable for the body masses of the giraffes in the study. The mean of those results was used to construct the allometric equation for that variable for giraffes. Confidence limits (95\%) and correlation coefficients were determined using the two variable geometric regression calculator available at www.benchmarkcalculations.com. Where appropriate, data were evaluated by the two-tailed t-test assuming unequal variances. $P$ values $<0.05$ were regarded as significant.

\section{Results}

Body mass. The range of body mass of the subset of 32 giraffes was $289-1441 \mathrm{~kg}$ for 16 males and for the 16 females was $399-1029 \mathrm{~kg}$. For the subset of 9 other giraffes it was 181 to $1396 \mathrm{~kg}$ ( 3 females, 6 males; Table 2A). Body mass and age are related and we estimated the age range of these giraffes to be six months to greater than 10 years (Mitchell et al, 2009).

Gastro-intestinal mass. The proportion that the mass of the rumen-complex contributes to body mass found in this study $(11.1 \pm 2.5 \%)$ and the proportion found by Hall-Martin et al $(12.8 \pm 0.4 ; 1977)$ who measured rumen-complex and intestine mass in the same manner as we have, and the proportions of the intestines (6.5 \pm 1.1 and $5.5 \pm 0.1$ respectively) did not differ significantly. In both studies the combined mass of the rumen-complex and intestines was on average ca18\% of body mass. On average in all giraffes culled in November and April there was no significant difference for the ratio of rumen-complex mass: body mass ratio $(11.1 \pm 3.0 \%$ and $10.8 \pm 1.9 \%$ respectively) nor for the intestine mass: body mass ratio $(6.4 \pm 1.1 \%$ and $6.4 \pm 0.8 \%$ respectively). There was no significant correlation between time of day and the ratio of rumen-complex mass: body mass $\left(R^{2}=0.1409\right.$, $\mathrm{P}=.1133$ ) but there was a significant correlation between time of day and intestine mass: body mass ratio $\left(\%=.39 * t^{\wedge} .4 ; \mathrm{CI}=.11-.69 ; \mathrm{R}^{2}=.3373, \mathrm{P}=.009\right)$. 
We found that the rate of increase in rumen-complex mass was negatively allometric $\left(\mathrm{Mb}^{\wedge} \cdot 64 \pm 0.14\right.$, Table $1 \mathrm{~A}$, isometry $=1.0$ ) relative to the rate of increase in body mass. The rate of increase in intestine mass was isometric relative to increases in body mass $\left(\mathrm{Mb}^{\wedge} .92 \pm 0.10\right.$, Table $\left.1 \mathrm{~A}\right)$. These growth patterns are illustrated in Fig 1.The combined small and large intestines formed $37.5 \pm 5.5 \%$ of total GIT mass and the rumen-complex $62.5 \pm 5.5 \%$. Interspecific analysis of rumen content mass in wild grazing ruminants has shown that it increases positively allometric relative to increases in body mass $\left(\mathrm{Mb}^{\wedge} 1.16 \pm 0.04\right.$; Table $\left.1 \mathrm{C}\right)$. If the rumen-complex mass of giraffes in our study was predicted by the equation for the rumen content mass of grazers it would on average have a mass significantly more than the measured mass of the entire rumen-complex $(144.1 \pm 72.9 \mathrm{~kg}$ versus $87.9 \pm 25.9 \mathrm{~kg}$; $\mathrm{P}<0.05$ ), on average constitute $18.2 \pm 1.6 \%$ of $\mathrm{Mb}$ (versus $11.1 \pm 2.5 \%$ ) and it would increase from $14.2 \%$ to $20.5 \%$ of body mass. If it was described by the equation of Clauss et al (2003A) it would on average be $14.0 \pm 2.3 \%$ of $\mathrm{Mb}$ and increase from $10.6 \%$ of $\mathrm{Mb}$ in a $289 \mathrm{~kg}$ giraffe to $19.3 \%$ of $\mathrm{Mb}$ in a $1441 \mathrm{~kg}$ giraffe. In giraffes the combined rumen-complex and intestine mass declines as body mass increases $\left(=63.4 * \mathrm{Mb}^{\wedge}-.20 \pm 0.08 ; \mathrm{R}^{2}=.1723 ; \mathrm{P}=.0226\right)$ from $20 \%$ of $\mathrm{Mb}$ in a giraffe weighing $289 \mathrm{~kg}$ to $15 \%$ in an adult weighing $1441 \mathrm{~kg}$.

Intestine length. The data shown in Table 1B and Fig 2 indicate that total intestine length in giraffes increases consistently with age $\left(\right.$ Length $(\mathrm{m})=43.5^{*}$ Age $\left.(\mathrm{yrs})^{\wedge} 0.18 ; \mathrm{CI}=0.15-0.21 ; \mathrm{R}^{2}=.9581\right)$ as does the length of the small $\left(29.1^{*} \mathrm{Age}^{\wedge} 0.12 ; \mathrm{CI}=0.07-0.18 ; \mathrm{R}^{2}=.8770\right)$ and large $\left(12.1^{*} \mathrm{Age}^{\wedge} 0.30\right.$; $\mathrm{CI}=0.16-0.44 ; \mathrm{R}^{2}=.8609$ ) intestines. Maximum length of the small intestine is reached at about 5 years of age, whereas the length of the large intestine, after increasing rapidly in early life, continues to elongate but more slowly (Fig 2). The average length of the small intestine in these giraffes was $36.4 \pm 11.8 \mathrm{~m}$ (mean $\pm \mathrm{s} . \mathrm{d}$ ) and for the large intestine was $18.9 \pm 7.5 \mathrm{~m}$. The length of the small intestine increases 2.5 fold and the large intestine 4.8 fold between the ages of 2 months and maturity. Nevertheless the small intestine length is always longer than large intestine length: the average ratio of small: large intestine length is $2.1 \pm 0.8$. Crisp (1866) also measured rumen length (1.74 m) and oesophagus length $(1.85 \mathrm{~m})$ in a giraffe as did Joly and Lavocat (1846) who found rumen length to be $1.6 \mathrm{~m}$ and oesophagus length $(1.4 \mathrm{~m})$ in their giraffe.

If the length of the small and large intestines in giraffes is computed from interspecific analyses of wild intermediate feeders/browsers as reported by Woodall and Skinner (1993; Table 1C) the predicted average length of the small intestine in the giraffes in our study is $39.4 \pm 8.5$ and for the large intestine is $21.8 \pm 5.4 \mathrm{~m}$, lengths that are not significantly different to the average, measured, lengths (Table 1B). The predicted ratio of small: large intestine length in giraffes also is similar $(1.8 \pm 0.1$; $\mathrm{P}=.5914)$. The average length of the small intestine in giraffes calculated from the lengths found in mature, wild grazing ruminants (Woodall and Skinner, 1993; Table 1C) is $50.8 \pm 15.1 \mathrm{~m}$ which is significantly longer than it is in browsers, the average large intestine length is significantly shorter in 
grazers $(13.0 \pm 2.2 \mathrm{~m})$, and the predicted ratio of small to large intestine in them is $3.8 \pm 0.6$.

The dimensions of the caecum of giraffes appear to change little during growth (Table 1B). In eight historical giraffes caecum length was $48 \mathrm{~cm}$ to $76 \mathrm{~cm}$. In the two measured by Perez et al. (2009) caecum length was found to be $44 \mathrm{~cm}$ and $96 \mathrm{~cm}$ respectively. Owen (1838) gave the diameter of the caecum as $4.8 \mathrm{~cm}$ and Joly \& Lavocat (1846) gave a diameter of $9.0 \mathrm{~cm}$. Its volume therefore can be estimated to be between 1.1 Litres in Owen's giraffe and 4.0 Litres in Joly and Lavocat's, both of which are smaller than direct observation suggests. Clemens \& Maloiy (1983) measured the contents of the caecum to be $9.2 \mathrm{~kg}$, which suggests that its volume is about 9 litres.

Parotid gland (grams), masseter muscle mass $(\mathrm{kg})$, mandible mass $(\mathrm{kg})$, tongue length $(\mathrm{cm})$ and mass $\underline{(\mathrm{kg})}$.

The allometric increase in the combined mass of both parotid salivary glands in 9 giraffes (Table 2A) is described by $1.05^{*} \mathrm{Mb}^{\wedge} .82 \pm .25\left(\mathrm{R}^{2}=.8958\right)$, with the average parotid mass being $0.034 \pm 0.01 \%$ of body mass, which is the smallest proportion of body mass so far recorded for it in a ruminant. The combined mass $(\mathrm{kg})$ of the masseter muscles $\left(0.001 * \mathrm{Mb}^{\wedge} 1.02 \pm 0.15 ; \mathrm{R}^{2}=.9726\right)$, was on average $0.14 \pm .02 \%$ of body mass, and the mass $(\mathrm{kg})$ of the mandible $\left(0.0036^{*} \mathrm{Mb}^{\wedge} 0.89, \mathrm{CI}=0.69-1.08\right.$, $\mathrm{R} 2=.9437$ ), was $0.18 \pm 0.03 \%$ of $\mathrm{Mb}$ (Table 2B). In all these cases the allometry shows that the rate of increase in mass of these elements as body mass increases cannot be distinguished from linearity because the confidence intervals are large (Parotid exponent $=.82 \pm .25$; Masseter 1.02 \pm .15 ; mandible $0.89 \pm .20$ ). Interspecific allometry of the parotid gland mass in mature African browsers (Table 3) shows that the mass of the gland declines as body mass increases (PG mass (g) $=0.40^{*} \mathrm{Mb}^{\wedge}$ $\left.0.32 \pm 0.09 ; \mathrm{R}^{2}=.8519\right)$ i.e. it scales with specific metabolic rate, a result that highlights the different conclusions that can arise from interspecific and ontogenic analyses. The ratio of masseter mass: mandible mass was on average $0.79 \pm 0.11$. Increases in tongue length $(\mathrm{cm})$ relative to increases in head length $(\mathrm{HL})$ was $=2.6 * \mathrm{HL}^{\wedge} .72\left(\mathrm{CI}=.51-.94 ; \mathrm{R}^{2}=.7269\right)$, and to body mass $=8.1 * \mathrm{Mb}^{\wedge} .32$ $\left(\mathrm{CI}=.25-.37 ; \mathrm{R}^{2}=.9505\right)$. Increases in tongue mass $(\mathrm{kg})$ was $=0.012 * \mathrm{Mb}^{\wedge} .69\left(\mathrm{CI}=.61-.77 ; \mathrm{R}^{2}=.9844\right)$. There were no significant differences between males and females for parotid gland mass as $\%$ body mass $(\mathrm{P}=.9402)$ or masseter mass $(\mathrm{P}=.6474)$ or mandible mass $(\mathrm{P}=.4605)$ or tongue length $(\mathrm{P}=.5956)$ or tongue mass $(\mathrm{P}=.5239)$.

Energy balance. Basal metabolic rate (BMR; kj/day) is not measurable in artiodactyls (White \& Seymour, 2002). What can be measured is Resting Metabolic Rate (RMR; $\mathrm{mlO}_{2} / \mathrm{kg}$. $\mathrm{min}^{-1}$ ) and it has been measured twice in giraffes (Patterson et al, 1965; Langman et al, 1982). Their results differ widely. Patterson et al's giraffes were wild, restrained, and anxious and RMR was approximately $6 \mathrm{ml} / \mathrm{kg}$. $\mathrm{min}^{-1}$. The three giraffes in Langman et al's study were accustomed to daily handling and RMR was measured in them 50 times. It was found to be $2.61 \pm 0.1 \mathrm{mlO}_{2} / \mathrm{kg}$. $\mathrm{min}^{-1}$, which is not 
significantly different to the BMR predicted by the allometric equations developed by Stahl (1967), Hayssen \& Lacy (1988) and Schmidt-Nielsen, (1997), and can be described by the allometric equation $9.7 * \mathrm{Mb}^{\wedge}-0.23\left(\mathrm{mlO}_{2} / \mathrm{kg}\right.$. $\mathrm{min}^{-1}$; Mitchell \& Skinner, 2011) or by $279.4^{*} \mathrm{Mb}^{\wedge} .77$ (kj/day). This latter estimate of RMR is not significantly different to the most commonly used estimate of BMR developed by Kleiber $\left(1961 ; 294 * \mathrm{Mb}^{\wedge} .75 \mathrm{kj} /\right.$ day $)$.

The FMR for the subset of 32 giraffes in this study was calculated to be $127 \pm 34 \mathrm{Mj} / \mathrm{day}$ (range 57-189 $\mathrm{Mj} /$ day) or $1472 \pm 393$ watts (mean $\pm \mathrm{SD}$; Table 4 ). It was on average $2.54 \pm 0.03$ times that of RMR. Pellew (1984A) used Kleiber's equation to estimate BMR and concluded that in the wet season males needed 1.4 times BMR for maintenance and females 1.75 times BMR. In the dry season males needed 1.55 times BMR and females 1.91 times BMR.

Our data indicate that of all energy produced by fermentation, the amount produced by the rumen declines as $\mathrm{Mb}$ increases from $74 \%$ in young giraffes to $61 \%$ in adults (Table 4). Conversely the amount produced by the hindgut increases from $26 \%$ in young giraffes to $39 \%$ in adults. Of the total energy required for FMR that supplied by rumen fermentation decreases from $49 \%$ to $39 \%$ and that supplied by hindgut fermentation increases from $17 \%$ to $25 \%$ as body mass increases. On average the rumen supplies $43 \%$ of FMR, and the hindgut $24 \%$. It follows that on average $33 \%$ is supplied by digestion of food, which, if it all occurs in the small intestine, is at a rate of $2705 \mathrm{kj} / \mathrm{kg} \mathrm{DM}$ ingesta/day.

Food Intake (kgDM/day). To meet FMR our calculations suggest that mean dry matter intake should be on average $15 \pm 4 \mathrm{~kg} /$ day ranging from $7 \mathrm{~kg}$ /day for a $289 \mathrm{~kg}$ giraffe to $23 \mathrm{~kg} /$ day for the adult weighing $1441 \mathrm{~kg}$ which corresponds to an average of $1.8 \pm 0.2 \%$ of body mass with young giraffe eating $c a 2.4 \%$ of body mass and adults $1.6 \%$ of $\mathrm{Mb}$ (Table 5 ). Feed intake derived empirically by Pellew (1984A) in adults was found to be between $1.6 \%$ and $2 \%$ of their body mass.

Nagy (2001) developed generic equations to describe DM food intake $\left(.07 * \mathrm{Mb}^{\wedge} .628\right)$ and fresh matter $\left(0.2 * \mathrm{Mb}^{\wedge} .628\right)$ in herbivores with fresh matter containing $70 \%$ water. These equations when applied to the giraffes in our study give ranges of feed intake of 2.3-6.3 kg/day and 7.0-19.2 kg/day for dry and fresh matter intake respectively which are lower than our estimates. Calder's (1996) equation for food intake $\left(.157^{*} \mathrm{Mb}^{\wedge} .84 \mathrm{~kg} /\right.$ day) gives values that are 3 times higher than our estimate, and it probably estimates fresh matter intake.

\section{Home Range (HR).}

Pellew's analysis of browse production rate (Pellew, 1983A) is exhaustive and meticulous but the data 
were obtained in the Serengeti and extrapolation to all parts of Africa that are home to giraffes is probably invalid. However, at the time the analysis was made browse productivity supported a population density of $1.47 \pm 0.54 / \mathrm{km}^{2}$ (Pellew, 1983A). Hall-Martin (1975) suggested that between 1.2 and 2 giraffe $\mathrm{km}^{-2}$ is the optimum carrying capacity of the South African Bushveld biome. Thus Pellew's calculation of a browse production rate of $186 \mathrm{watts} / \mathrm{km}^{2}$ may give an estimate of the minimum home range needed by giraffes generally to supply the energy for FMR. FMR scales with $\mathrm{Mb}^{\wedge} .74$ (Table 4) and because a basic assumption is that the size of the core or minimum HR is determined by the relationship between body mass and metabolic rate (McNab, 1963) minimum HR also scales with $\mathrm{Mb}^{\wedge} .74$ (Table 5). Our calculations show that minimum HR for giraffes of the body mass we have measured is on average $7.9 \pm 0.21 \mathrm{~km}^{2}$ when browse production rate is 186 watts. $\mathrm{km}^{-2}$, and increases as body mass increases from $0.36 \mathrm{~km}^{2}$ for a $289 \mathrm{~kg}$ giraffe to $1.17 \mathrm{~km}^{2}$ for a $1441 \mathrm{~kg}$ giraffe. The minimum feed intake from HR to meet FMR was on average $1.9 \mathrm{~kg}$ DM/day. $\mathrm{km}^{-2}$.

\section{Discussion}

The primary daily goal of any animal is to obtain sufficient energy from its food sources, and central to any analysis of digestive morphophysiology is how that energy is extracted from food, but measurement of how much energy is required by an animal is difficult and sometimes impossible. Until the introduction of the doubly-labelled water method, estimation of the energy requirements of an animal depended on measuring its oxygen consumption and carbon dioxide excretion using complex equipment. Two types of metabolic rate could be measured - basal metabolic rate and resting metabolic rate. Basal metabolic rate is the oxygen consumption measured in an inactive, postabsorptive, non-reproductive, adult animal, thermoregulating in a thermoneutral environment (White $\&$ Seymour, 2002), a set of constraints which makes it impossible to measure in large animals in general and ruminants in particular: ruminants are never, for example, in a post-absorptive state. Resting metabolic rate is easier to measure. It is the oxygen consumed by an animal not exercising, not anxious, not digesting food and in a thermoneutral environment, a group of criteria that is less restrictive but nevertheless difficult to achieve, but it has been successfully measured in giraffes (Langman et al, 1982). The doubly-labelled water method measures Field Metabolic Rate, which is the daily energy consumption of an animal exposed to all the activities of daily life. It is a true costof-living (Nagy, 1987). The method measures the rate of incorporation of radioactive isotopes of oxygen and hydrogen into carbon dioxide and water and the methodology (an injection) is relatively simple. Its cost, however, has limited its use to relatively small animals with relatively low metabolic rates of up to $52500 \mathrm{kj} /$ day. The largest ruminant so far assessed had a body mass of $39 \mathrm{~kg}$.

Extrapolations to ruminants larger than this requires caution, but as FMR and its associated daily food needs are determined primarily by body mass, estimations of FMR from body mass are made routinely even though other factors such as seasonal variations, reproduction, lactation and growth 
contribute to FMR (Nagy, 2001; 2005). Our analyses of energy provision in this study are based on estimates of FMR based on the body masses of giraffes much higher than $39 \mathrm{~kg}$, and we acknowledge the potential inaccuracies that could arise.

In ruminants, supplying energy for metabolism depends on having a gastrointestinal tract that increases in size in proportion to body mass. "Size" can mean volume (Demment, 1982; Weckerly, 2010), or tissue mass (Luna et al, 2012), or capacity, which is the usual measure (Demment, 1982; Demment and van Soest, 1985) and means the contents. We have measured the combination of contents and tissue mass. In wild giraffes our analyses show that relative to the rate of increase in body mass, the rate of increase in the mass of the rumen-complex is negatively allometric, and that of the intestine mass is isometric (Table 1A, Fig 1). Analysis of intestine length shows that it increases rapidly in the early years of life with the small intestine reaching its maximum length before the large intestine does (Table 1B, Fig 2). The mass of the intestines continues to increase even though maximum length has been reached reflecting increases in content mass rather than tissue mass. Compared to the lengths of intestines in wild grazing ruminants measured by Woodall and Skinner (1993) giraffes have shorter small intestines and longer large intestines (Table 1C), which conforms to the general pattern found in other wild browsers, but is significantly different to those found in wild grazers. During growth the combined small and large intestine mass increases eight-fold and that of the rumen-complex four-fold. This difference is also illustrated by the difference in the exponents for the relative growth rate of the rumen-complex (0.64) and intestines $(0.92)$.

The negatively allometric nature of increases in rumen-complex mass means that although the absolute mass of the rumen-complex increases throughout life it forms a progressively smaller proportion of body mass. Weckerly (2010), also using ontogenic data, found the same relationship for rumen-reticulum mass in another browser, white-tailed deer. In wild grazing ruminants increases in the relative rumen-reticulum mass have an opposite pattern, forming a larger proportion of body mass in large grazers than in smaller ones. Interspecific studies of the kind that have been done on mature grazing ruminants do not necessarily describe changes that may have occurred in the mass of their rumen-reticulum as they grow. So it is possible that the difference in growth patterns is an artefact arising from comparison of our ontogenic data with interspecific data obtained from mature wild grazing ruminants with a range of body masses. This possibility can only be confirmed or refuted by an ontogenic analysis of the growth pattern of the gastrointestinal tract of a grazer. Nevertheless we have concluded that compared to wild grazing ruminants giraffes of equivalent body mass have significantly smaller rumens and a growth pattern that is different.

The proportion that the rumen-complex contributes to body mass is constant between November (11.8\%; late dry to early wet season) and April (10.8\%; late wet season). It is also constant between 
early morning $(0600 \mathrm{~h})$ and late afternoon $(1700 \mathrm{~h})$ which confirms that browsing starts before sunrise in the morning and that it fills a large part of a giraffe's day as observed by du Toit \& Yetman (2005). However, the mass of the intestines is significantly correlated with time of day, is lowest in the early morning and highest in the late afternoon, with time of day accounting for approximately $34 \%$ of the variation, with much of the residual variation attributable to difficulties of making accurate measurements in the field. From the relationship between time of day and intestine mass, intestine mass can be predicted to be $5 \%$ of body mass $(50 \mathrm{~kg}$ ) in a $1000 \mathrm{~kg}$ giraffe in the morning and $7.6 \%$ of $\mathrm{Mb}(76 \mathrm{~kg})$ in the afternoon i.e. a substantial $26 \mathrm{~kg}$ difference in mass. Giraffes obtain much of their water from browse so the difference is not likely to be a consequence of drinking free water. Daily dry matter intake of a $1000 \mathrm{~kg}$ giraffe can be predicted to be $17 \mathrm{~kg}$ (Table 5) and if water content is $70 \%$ (Nagy, 2001) then simultaneous water intake will be approximately $55 \mathrm{~kg}$. If so, then an explanation for the variation in intestine mass over the course of a day, and also confirmation of their feeding habits as described by Dagg (1960), is that during the day most browsing occurs and the intestines (and rumen-complex) fill with ingesta. Digestion and absorbtion of water and nutrients and excretion of waste is slower than increases in feed intake. At night when browsing is infrequent, the digestive, absorptive and excretory processes exceed the rate of intestine filling from the rumen so that by morning intestine mass has declined.

A consequence of having a rumen-complex the relative mass of which declines with growth and an intestine the relative mass of which increases during growth is that the source of fermentation energy changes during growth. As fermentation occurs mostly in the rumen and hindgut, the change in the source of fermentation mirrors the changes in intestinal anatomy. The increase in the mass of the intestines during growth that we have found may be an artefact of our method. We did not remove the mesenteries or attempt to measure the mass of the adipose tissue, and as mature animals accumulate more adipose tissue in the mesenteries of the intestine than young animals do, the mass of the intestines we measured may change for this reason and not for a morphological or physiological one. However, the mass of the rumen-complex as a percentage of $\mathrm{Mb}$ falls from ca20\% in a neonate to ca15\% in an adult, the total length of the intestines more than doubles during growth (Table 1B), while the proportion of $\mathrm{Mb}$ that the intestine mass forms stays relatively constant falling from $7.4 \%$ to $6.1 \%$ of $\mathrm{Mb}$. We have concluded therefore that it is the size of the intestines that changes and this change is the cause of the shift in fermentation from the rumen to the hindgut as a giraffe matures.

Another consequence is that, despite their size, giraffes must have evolved digestive processes that do not rely on a large rumen to acquire the energy to support their metabolism as is the case in grazers. They must depend on the contributions made by other parts of the gastrointestinal tract and/or by more efficient extraction of energy from browse. Demment and van Soest (1985), van Soest (1996), Clauss et al. (2003A; 2007; 2009), and Muller et al. (2013) have suggested that extraction of energy 
does not only depend on the size of the gastrointestinal tract. Efficient energy extraction also depends on digestibility and fermentation rate of browse, on reduction in particle size by rumination, a longer retention time of ingesta, and selection for diets of high quality, or optimal combinations of these.

Although it is generally accepted that the fermentation rate of browse is faster than it is of grass (du Toit and Yetman 2005; Hummel et al, 2006) because of the differences in insoluble fibre content, the rate of VFA production from DM in giraffes is similar to that of other wild ruminants including grazers (Maloiy et al, 1982; Gordon and Illius, 1994). Reduction in particle size by rumination in giraffes to increase digestibility occupies a relatively short part of their day: they allocate a disproportionate time to feeding compared to rumination (du Toit and Yetman 2005), which implies that the size of the particles that enter the rumen stimulate the rumination reflex relatively infrequently. Giraffes on average spend 13 hours/day feeding and 4.5 hours/day ruminating (Leuthold \& Leuthold, 1972; Pellew, 1984B; du Toit and Yetman 2005). By comparison, a grazing wild ruminant such as a buffalo in the same environment as giraffes on average feeds for 9.2 hours a day and ruminates for 7.1 hours/day (Grimsdell and Field, 1976; Beekman and Prins, 1989; Ryan and Jordaan, 2005). Mature kudu, the next largest obligate African browser have a body mass of $240 \mathrm{~kg}$, eat approximately one-third of the browse DM/day that a giraffe does, use the same browse as giraffe as the source of nutrients, but spend 8 hours/day feeding and 5 hours/ day ruminating (du Toit and Yetman 2005). A reason that giraffes spend more time feeding is that they need to acquire more absolute amounts of feed and, because it comprises shoots, leaves and florets, need more time to acquire it (du Toit and Yetman 2005).

Ingestion, chewing, and rumination depend to a large extent on the tongue to grasp browse, and on the masseter muscles to elevate the mandible against the maxilla. The tongue of giraffes has long impressed observers with its power, length, and flexibility (Home, 1828; Owen, 1838; Hofmann, 1989). The combination of changes during growth in its length and mass we have found (Table 2B) shows that its length, rather like the length of the intestines, reaches its maximum relatively early in a giraffe's life. Its mass, which is mainly muscle, continues to increase linearly with increases in body mass as do mandible and masseter mass. We have previously reported that the growth rate of masseter muscles is positively allometric relative to the growth rate of body mass although as the $95 \%$ confidence intervals for the exponent fell above and below unity, the rate of increase in their mass is linear with respect to increases in body mass (Mitchell et al, 2013). The data we show here for the subset of 9 giraffes in which we also measured parotid gland mass, mandible mass and tongue length and mass confirms that increases in masseter muscle mass is linear relative to body mass and that their mass increases from about 500 grams in a juvenile to over $3 \mathrm{~kg}$ in a mature adult.

In giraffe the masseters have their origin on the facial bone crest and its tuberosity and on the bones of 
the zygomatic arch of the skull, and its fibres are directed obliquely downwards and backwards to insert on the lateral surface of the mandible (Sasaki et al, 2001). It has three layers: superficial, middle and deep (Sasaki et al, 2001) and it inserts further back on the mandible than it does in the cow which allows giraffes to open their mouth somewhat wider (Hofmann, 1989). It functions to draw the mandible forward and upward. It has been suggested that it is a multipennate muscle (Sasaki et al, 2001) which allows increased force of contraction but a smaller range of motion and slower contraction rate, and this would seem to be appropriate for rumination. The combination of masseter muscle action and brachydont, selenodont molars is perfectly adapted for crushing browse, and it may be that the longer feeding time and the shorter rumination time of giraffes is because they spend time reducing particle size at the time of browsing.

Although Axmacher and Hofmann (1988) concluded that mass of masseter muscles in grazers and browsers does not differ significantly $(0.20 \pm 0.04$ and $0.21 \pm 0.05 \%$ of body mass respectively) subsequent analysis of their data and additional data by Clauss et al (2008) concluded that browsers had smaller masseter muscles than grazers because the fibre content of grass is greater and harder to reduce during rumination than it is to reduce browse. However, in the subset of African browsers in their data (listed in Table 3$)$, the masseter masses $(0.20 \pm 0.05 \%$ of body mass) were not significantly different from those in grazers $(0.20 \pm 0.03 \% ; \mathrm{P}=.9134)$. In our giraffe masseter muscle mass was $0.14 \pm 0.02 \%$ of body mass which is significantly smaller $(\mathrm{P}<0.05)$, but the same as that reported by Clauss et al (2008) for a single giraffe weighing $800 \mathrm{~kg}$ and which had a masseter mass of $1.03 \mathrm{~kg}$. The ratio of masseter mass to mandible mass is another indicator of the forces needed to reduce feed to manageable proportions. In ruminant herbivores the average ratio is 1.30 versus 2.4 in nonruminant herbivores and 3.0 in carnivores (Clauss et al, 2008) and it is lower in ruminants because rumination is performed on digesta softened by a stay in the rumen which reduces the load on the masticatory apparatus (Archer \& Sanson, 2002). We found the ratio to be $0.79 \pm 0.11$ in our giraffes, lower than the average value for ruminant herbivores in general. If the ratio in ruminants typically is 1.3 and their masseter mass $0.20 \%$ of body mass then mandible mass will be $0.15 \%$ of body mass, which is similar to the relative mass of the mandibles in giraffes $(0.18 \%)$. The lower ratio in giraffes must, therefore, be because their masseter muscles are smaller, and we have to conclude that masseter mass in them is determined by the succulence of the browse they select.

A long retention time of ingesta in the rumen and its associated longer time for fermentation would also increase energy extraction. Retention time in the rumen depends on the size of the particles entering the rumen and the associated size of the surface area available for microbial fermentation. By necessity estimates of mean retention time in ruminants have been derived from captive animals and not free-living animals eating their natural food. Measurements of retention time of fluid and particles in the whole digestive tract have been made by Clauss et al (1998) in three captive giraffes of 
estimated body mass 1000,850 and $700 \mathrm{~kg}$. In them fluid and particle retention time averaged $33.7 \pm 5.0$ and $40 \pm 7.2$ hours respectively. The ratio of particle retention time to fluid retention in the rumen was on average $1.4 \pm 0.1$ implying that fluid moved out of the rumen faster than particulate matter. In other studies retention time in a giraffe of estimated body mass of $1000 \mathrm{~kg}$ was 48 hours which was less than the retention time (52.7 hours) of an Asian Buffalo of mass $417 \mathrm{~kg}$ (Clauss et al, 2003A), and a particle retention time of $22.5 \pm 7.0 \mathrm{~h}$ in a giraffe has been recorded (Clauss et al, 2006). The allometric retention time for ruminants in general is described by the equation $.695^{*} \mathrm{Mb}^{\wedge} .22$ (days; Demment and van Soest, 1985; Illius and Gordon, 1992), and gives a retention time of 72.4 hours for a $1000 \mathrm{~kg}$ giraffe. Overall the conclusion must be drawn that Clauss et al's (2003 A; 2006) estimates $\left(13.7 * \mathrm{Mb}^{\wedge} .18\right.$; range $1.4-2.1$ days) are the best available for retention time of ingesta in a giraffe. If so, rumen retention time could be as short as 33 hours in a young giraffe and 50 hours in a mature adult male. Short retention times imply that digestion/fermentation of browse is relatively quick, that intake is not limited by a full rumen, and that more browse can be consumed and more energy produced per unit time.

If GIT capacity of giraffes does not increase linearly as $\mathrm{Mb}$ increases, if retention time is relatively short, and if fermentation is not unusually efficient nor dependent on prolonged rumination, then, we have concluded, the most important digestive adaptation that giraffe have evolved is the ability to select high quality browse. It is a commonplace observation that giraffes are highly selective browsers. For example, Leuthold and Leuthold (1972) found that of 66 plant species sampled by giraffes five supplied $67 \%$ of their diet, but how important selection of browse might be for improving energy extraction has not been emphasized. The outcome of selectivity is that the quality of browse they eat is always high (Hall-Martin and Basson 1975; Pellew 1984A). Acquisition of browse is a complex process relying on taste and smell and in giraffes it is facilitated by a long prehensile tongue, mobile lips and modified teeth and maxilla. It also depends on vision. Most browsing occurs during daylight hours when their ability to distinguish colour (Backhaus 1959), and their visual acuity facilitates browse selection. Visual acuity is related to the size of the surface area of the retina and thus the number of photoreceptors present, both of which are larger in giraffes than in all other ungulates (Schiviz et al. 2008; Mitchell et al. 2013B) and to the types and the way in which the photoreceptors are distributed in the retina (Schiviz et al, 2008; Coimbra et al, 2013). In giraffes the characteristics and distribution of their photoreceptors confer an ability to distinguish fine detail and allow visual guidance of the tongue and lips (Coimbra et al, 2013). They also have a unique tapetum lucidum which enhances vision in mesopic light (Coimbra et al, 2013). Moreover, with age their visual field becomes more binocular and near distance stereoscopic visual acuity increases (Mitchell et al. 2013B). Stereoscopic vision, together with their ability to discriminate between closely spaced objects that the large number of photoreceptors confers, enhances their ability to discriminate between sizes and shapes of browse and thus selectivity. 
The nature of giraffe browse is that the nutrients derived from cell contents comprise $64 \%$ of total nutrients (Pellew 1984B) and these are released during ingestion and chewing (Hofmann. 1989; Archer \& Sanson, 2002). Cell contents usually are in the form of soluble stored carbohydrates such as starch or sugars or lipids and proteins that do not need to undergo fermentation. They can be digested by enzymes secreted into the small intestine and after digestion absorbed from there. The length of the small intestine of giraffes is $65 \%$ of total intestine length (Table 1B) and it is the main site of digestion and absorbtion of all nutrients that escape absorbtion in the rumen as well as nutrients that bypass the rumen. The advantage of rumen bypass is that loss of carbohydrate energy by fermentation is avoided. The mechanism of bypass as proposed by Hofmann (1989) is via the oesophageal (ventricular) groove, although there is some evidence from North American captive ruminants fed an artificial diet that this mechanism may not function in adults (Lechner et al, 2009). The groove is quite short in okapi $(2-5 \mathrm{~cm})$ and giraffes $(8 \mathrm{~cm})$ compared to that in cattle $(20 \mathrm{~cm}$; Burne, 1939).

The anatomy of the salivary glands of giraffes has been described by Perez et al (2012) and as in other animals the three main glands are the parotid, mandibular and sublingual, of which the parotid gland is the largest and most important. There have been two previous measurements of their mass by Robbins et al (1995) and Hofmann et al, (2008). Robbins et al provided no details of their mass. Hofmann et al's data covered 62 species of ruminant, including three giraffes with an average body mass of $515 \mathrm{~kg}$ in which the parotid weighed an average of 308.5 grams ( $0.06 \%$ of body mass), and data from one giraffe that had a body mass of $395 \mathrm{~kg}$. The mass of its mandibular gland was $272 \mathrm{~g}$ ( $0.07 \%$ of body mass), its ventral buccal gland $77.1 \mathrm{~g}(0.02 \%)$ and its sublingual $38.8 \mathrm{~g}(0.01 \%)$. Hofmann et al's data also included an okapi and its parotid gland weighed $0.07 \%$ of body mass. These data and the data for 10 other African browsers extracted from their data list, and defined as browsers by having $10 \%$ or less grass in their diets, are shown in Table 3 . They show that gland mass declines as body mass increases, and confirm that it correlates well with metabolic rate as proposed by Kay (1987) and Hofmann et al (2008). If so it will be small in large browsers. The data we report in this study for nine giraffes show that the mass of the glands increases linearly with increases in body mass and that average parotid mass forms a constant $0.034 \pm 0.01 \%$ of body mass, a result quite different to that predicted by interspecific allometry. Between species gland size may correlate with metabolic rate. Within a species gland size correlates with body mass.

The size of the glands in giraffes (and okapi), which is relatively far smaller than in any other ruminant, clearly has a genetic component and perhaps an epigenetic one as it may be affected by the consistency of the diet with diets providing mechanical stimulation leading to hypertrophy (Kay, 1987), by the volume of saliva produced (Hofmann, 1989), by the amount of tannin neutralizing 
proteins secreted (Robbins et al, 1995), and /or variation in habitat, variation with seasons, increasing in summer and regressing in winter, and dissection technique (Hofmann et al, 2008). Hofmann et al also suggested that the small parotid gland in okapi and giraffes could be complemented by comparatively large mandibular, buccal and sublingual glands. However this conclusion is not supported by their data. The relative masses of the mandibular $(0.07 \%$ of $\mathrm{Mb})$, buccal $(0.02 \%)$ and sublingual $(0.01 \%)$ glands are not larger than they are in other African browsers (Table 3). Analysis of Robbins et al's suggestion that size is related to tannin neutralizing proteins gives an inconclusive result. Furstenburg and van Hoven (1994) found that for giraffe browse the tannin in young leaves in November is $10.0 \pm 8.1 \%$ of dry matter and in mature leaves in April it is $5.3 \pm 5.0 \%$. Owen-Smith (1997) measured tannin concentrations in browse eaten by kudu, which in many cases overlaps with giraffe (Dougall et al 1964), and found a similar result: tannin concentration is highest in November (3.3\%) and lowest in April-June (2.4\%). The time of year in which the data for Hofmann et al's giraffe were collected is not known, but in our study parotid glands were obtained from giraffe culled in November, when tannin concentrations are highest and the glands small, although as we did not collect data on gland mass in April we cannot compare relative size across seasons.

Saliva secretion rate is stimulated by eating (Kay, 1987) and varies with dry matter intake and bite size (Robbins et al, 1995). In giraffe it varies with browse height (Young \& Isbell, 1991), bite size varies between 2.5 (Pellew, 1984B) to 0.5 grams per bite (Young \& Isbell, 1991) and they take 15-30 bites a minute (Pellew, 1984A; Young \& Isbell, 1991). Kay (1987) found that feeding increased secretion rate 4-fold in goats and Robbins et al (1995) measured a secretion rate of 3-16ml/gramDM intake in a browser. Applying these rates to giraffes, their parotid gland could secrete between $1.1 \pm 0.2$ and $3.2 \pm 1.5 \mathrm{ml}$ of saliva per gram of gland per minute while they are browsing (Table $2 \mathrm{~A}$ ).

We have calculated that the amount of energy obtained from digestion in the intestines of giraffes is on average $35 \%$ of energy needs and on average for the giraffes of the body mass in this study is equivalent to $2.3 \pm 0.7 \mathrm{~kg} /$ day of soluble carbohydrate which is easily met by the amount consumed by adult giraffes (6.6kg/day; Pellew, 1984B). In wild African intermediate feeders/browsers the absorptive surface of the small intestine length is related to intestine length $\left(0.022^{*}\right.$ length^${ }^{\wedge} 1.7$; $\mathrm{CI}_{\mathrm{exp}}=1.4-2.0 ; \mathrm{R}^{2}=.9628$; Woodall and Skinner, 1993; Table 1C). The length of giraffe small intestine increases from $24.7 \mathrm{~m}$ in a two month-old giraffe to $59.7 \mathrm{~m}$ in a mature male (Table 1B). Assuming that the relationship between absorptive surface area and length follows the pattern of other African intermediate feeders/browsers, the corresponding change in absorptive surface area in giraffes is from $5.1 \mathrm{~m}^{2}$ to $23.0 \mathrm{~m}^{2}$. In other words small intestine length increases 2.4 fold but surface area 4.5 during growth. The length of the large intestine increases from $5.8 \mathrm{~m}$ in a 2 month-old giraffe to $27.7 \mathrm{~m}$ in a 21 year-old. Following Woodall and Skinner (1993) its absorptive surface area is related to length by $.25 *$ length $1.45\left(\mathrm{CI}_{\exp }=1.3-1.6 ; \mathrm{R}^{2}=.9845\right)$ and increases 10 -fold from 3.2 to $30.9 \mathrm{~m}^{2}$. It supplies an 
increasing amount of fermentation energy and in addition it reabsorbs water and electrolytes (Hofmann 1989; Clauss et al. 2003A) which are essential functions for the survival of an arid-adapted animal.

\section{Home range}

The minimum HR of giraffes, which scales with $\mathrm{Mb}^{\wedge} .74$, is much smaller than actual or predicted $\mathrm{HR}$, which on average scales with $\mathrm{Mb}^{\wedge} 1.27$ (Table 5). Why? It is possible that their tallness and the access it gives them to browse not available to other animals are not taken into account when giraffe $\mathrm{HR}$ is predicted from equations developed from the ecology of other mammals. Other reasons may include a search for high quality food, the ecological pressure of having to share local resources with conspecifics (Jetz et al. 2004), or with elephants, or with other browsers (Berry 1978; du Toit 1990C) or a search, in the case of males, for receptive females, or age, with older animals having a larger HR than younger ones (Langman, 1973; Berry,1978; VanderWaal et al. 2014), and edaphic and physiographic factors (Berry 1978), with "homeless" subadult males wandering widest. It is clearly a very complex set of interactions, the integration of which for any individual wild giraffe can only be guessed. Furthermore, while it is usually assumed that the meanderings are purpose driven, they may be whimsical. They wander because they can, and the energetic cost of doing so is low.

Direct measurement of HR of giraffes in the Kruger National Park in South Africa found it to be 282 $\mathrm{km}^{2}$ (du Toit, (1990C) compared to $163 \mathrm{~km}^{2}$ in Tsavo (Leuthold and Leuthold, 1978), 62-85 km² in Nairobi National Park in Kenya (Foster and Dagg, 1972), 68.2 \pm 7.0 in Kenya (VanderWaal et al. 2014), $79 \pm 27 \mathrm{~km}^{2}$ in the Luangwa National Park in Zambia (Berry 1978), and about $25 \mathrm{~km}^{2}$ in the Timbavati Nature Reserve in South Africa (Langman 1973), which are consistent with the predicted average HR of $68.9 \pm 37.8 \mathrm{~km}^{2}$ (Table 5). In the Namibian desert their home range approaches 2000 $\mathrm{km}^{2}$ (Fennessy, 2009). A home range of $c a 70 \mathrm{~km}^{2}$ that has a browse production rate of 186 watts. $\mathrm{km}^{-2}$ would, on average, be able to be shared with 100 other giraffes and the population density would be 1.6 giraffe $/ \mathrm{km}^{2}$. It could accommodate a typical group of giraffes: most groups (75\%) comprise fewer than six individuals (Dagg \& Foster 1976). The composition of groups is highly fluid but a group of six might consist of 1-2 adult males, 2-3 adult females and 1-2 young (Dagg \& Foster 1976). The average population density for giraffes in Africa reported by Innis (1958) (South Africa), Dagg and Foster (1976) (30 sites across Africa), Hall-Martin (1974; 1975) (South Africa), and Pellew (1983A) (Serengeti) is $1.3 \pm 0.7$ per $\mathrm{km}^{2}$ (range.01-14.1).

Contrary to the predictions and impressions obtained from interspecific analysis of the dimensions of the components of the digestive system of ruminants, that variables linked to the process of food intake correlate with metabolic rate (Hofmann et al 2008) or feeding type (Axmacher \& Hofmann, 
1988; Hofmann, 1989) and that increases in mass of the components of the gastrointestinal tract increase linearly with body mass (Demment, 1982; Demment \& van Soest, 1985; Clauss et al, 2003A), our data show that ontogenic analysis, in particular in an obligate browser, the giraffe, leads to different conclusions. In giraffes the mass of the parotid salivary glands, mandibles, and masseter muscles all scale linearly with body mass and not with metabolic rate, and they do not conform with feeding type. Similar conclusions can be drawn about rumen and intestine mass. In giraffes rumen mass scales hypoallometrically with body mass, and the mass of the intestines scale isometrically, with the result that fermentation shifts during growth from the rumen to the hindgut and digestion in the small intestine assumes an important role. The total mass of the gastrointestinal tract, as a proportion of body mass, declines with growth. In short the data reported in this study indicate that giraffes have a relatively small rumen, short small intestine, and long large intestine. Their rumination and retention times are short because their masticatory apparatus reduces browse to small particles at the time of feeding. Fermentation of ingesta in the rumen and hindgut is the principal source of energy, but a third of all energy to support metabolism is derived from digestion of nutrients that enter the small intestine in the form of soluble carbohydrates, lipids and proteins. The supply of energy relies on their ability to select high quality browse acquired from a large home range and some unique morphophysiological attributes of their digestive system.

\section{Acknowledgements}

The management and staff of the Bubye Valley Conservancy, Zimbabwe are thanked for their logistical support and sponsorship of this study. Funds were provided by the Don Craib Trust and the University of Wyoming. Technical field support was provided by Kenneth Manyangadze, Mark Brewer, Blake Wilelmi, Lauren Leathem, Kyle Pearse, Declan Gallagher, and Megan North. Without the work and support of the late Prof John Skinner this study would not have been completed.

\section{References}

Archer, D., Sanson, G. 2002. Form and function of the selenodont molar in southern African ruminants in relation to their feeding habits. J.Zool.(Lond.). 257,13-26.

Axmacher, H., Hofmann, R.R. 1988. Morphological characteristics of the masseter muscle of 22 ruminant species. J. Zool. (Lond.). 215, 463-473.

Backhaus, D., 1959. Experimentelle Prüfung des Farbsehvermögens einer Massai-giraffe (Giraffa camelopardalis tippelskirchi Matschie 1898). Z. Tierpsychol. 16, 468-477.

Beddard, J. E., 1902. The Cambridge Natural History. Volume 10. Mammalia. London, Macmillan. Beekman, J.H., Prins, H.H.T., 1989. Feeding strategies of sedentary large herbivores in East Africa, with emphasis on the African buffalo, Syncerus caffer. Afr. J. Ecol. 27, 129-147.

Berry, P.S.M., 1978. Range movements of giraffe in the Luangwa Valley, Zambia. E. Afr. Wildl. J. 16, 77-83. Burne, R.H. 1939. Description of the stomach, intestine, liver, and pancreas of the okapi, Okapia johnstoni. Proc. Zool. Soc. B. 109, 451-479.

Calder, W.A., 1996. Size, Function, and Life History. Dover Publications, Inc. Mineola, New York. Cameron, E.Z., du Toit, J.T., 2007. Winning by a neck: Tall giraffes avoid competing with shorter browsers. Am. Nat. 169(1), 130-135.

Clauss, M., Deutsch, A., Lechner-Doll, M., Flach, E., Tack, C., 1998. Passage rate of fluid and particle phase in 
captive giraffe (Giraffa camelopardalis). Adv. Ethol. 33, 98.

Clauss, M., Frey, R., Kiefer, B., Lechner-Doll, M., Loehlein, W., Polster, C., Rössner, G.E., Streich, W.J., 2003A. The maximum attainable size of herbivorous mammals: morphophysiological constraints on foregut, and adaptations of hindgut fermenters. Oecologia. 136, 14-27.

Clauss, M., Hofmann, RR., Streich, WJ., Fickel, J., Hummel, J. 2008. Higher masseter muscle mass in grazing than in browsing ruminants. Oecologia. 157, 377-385.

Clauss, M.A., Hummel, J.B.C., Streich, W.J.D., 2006. The dissociation of the fluid and particle phase in the forestomach as a physiological characteristic of large grazing ruminants: an evaluation of available, comparable ruminant passage data. Eur. J. Wildlife Res. 52, 88-98.

Clauss, M., Lechner-Doll, M., Streich, W.J. 2003B. Ruminant diversification as an adaptation to the physicomechanical characteristics of forage. A reevaluation of an old debate and a new hypothesis. Oikos. 102: 253-262.

Clauss, M., Nunn, C., Fritz, J., Hummel, J., 2009. Evidence for a tradeoff between retention time and chewing efficiency in large mammalian herbivores. Comp. Biochem.Physiol.A. 154, 376-382.

Clauss, M., Schwarm, A., Ortmann, S., Streich, W.J,, Hummel, J., 2007. A case of non-scaling in mammalian physiology? Body size, digestive capacity, food intake, and ingesta passage in mammalian herbivores. Comp. Biochem. Physiol. A. 148, 249-265.

Clemens, E.T., Maloiy, G.M.O., 1983. Digestive physiology of east African wild ruminants. Comp. Biochem. Physiol. A. 76(2), 319-333.

Coimbra, J.P., Hart, N., Collin, S.P., Manger, P.R. 2013. Scene from above: retinal ganglion cell

topography and spatial resolving power in the giraffe (G camelopardalis). J. Comp. Neurol. 521, 2042-2057.

Crisp, E., 1864A. Contributions to the anatomy of the giraffe, with an account of the length of the alimentary

canal of many other ruminants. Proc. Zool. Soc. (Lond.). 1864, 63-68.

Crisp, E., 1864B. Further contributions to the anatomy of the giraffe and the nylghau. Proc. Zool. Soc. (Lond.). 1864, 269- 271.

Crisp, E., 1866. Further observations relating to the anatomy of the giraffe. Proc. Zool. Soc. (Lond). 1866, 563566.

Dagg, A.I. 1960. Food preferences of the giraffe. Proc. Zool. Soc. (Lond.). 135, 640-642.

Dagg, A.I., Foster, J.B., 1976. The giraffe: Its biology, behaviour, and ecology. Van Nostrand Reinhold, New York.

Demment, M.W., 1982. The scaling of ruminoreticulum size with body weight in East African ungulates. Afr. J. Ecol. 20, 43-47.

Demment, M.W., van Soest, P.J., 1985. A nutritional explanation for body-size patterns of ruminant and nonruminant herbivores. Am. Nat. 125(5), 641-672.

Dougall, H.W., Drysdale, V.M., Glover, P.E. 1964. The chemical composition of Kenya browse and pasture herbage. E. Afr. Wildl. J. 2, 86-121.

du Toit, J.T., 1990A. Feeding-height stratification among African browsing ruminants. Afr. J. Ecol. 28, 55-61.

du Toit, J.T., 1990B. Giraffe feeding on Acacia flowers: predation or pollination? Afr. J. Ecol. 28, 63-68.

du Toit, J.T., 1990C. Home range: Body mass relations: A field study on African browsing ruminants.

Oecologia. 85(2), 301-303.

du, Toit, J.T., Yetman, C.A., 2005. Effects of body size on the diurnal activity budgets of African browsing ruminants. Oecologia. 143, 317-325.

Fennessy, J. 2009. Home range and seasonal movements of Giraffa camelopardalis angolensis in the northern Namib desert. Afr. J. Ecol. 47, 318-327.

Foster, J.B., Dagg, A.I., 1972. Notes on the biology of the giraffe. E. Afr. Wildlife J. 10, 1-16.

Furstenburg, D., van Hoven, W. 1994. Condensed tannin as anti-defoliate agent against browsing by giraffe (Giraffa camelopardalis) in the Kruger National Park. Comp. Biochem. Physiol. A. 107(2), 425-431.

Giesecke, D., van Gylswyk, N.O., 1975. A study of feeding types and certain rumen functions in six species of South African wild ruminants. J. Agri. Sci., Cambridge. 85, 75-83.

Ginnett, T.F., Demment, M.W., 1997. Sex differences in giraffe foraging behaviour at two spatial scales. Oecologia. 110, 291-300.

Goetz, R.H., Budtz-Olsen, O., 1955. Scientific safari- the circulation of the giraffe. S. Afr. Med. J. 29, 773-776.

Gordon. I.J., Illius, A.W., 1994. The functional significance of the browser-grazer dichotomy in African ruminants. Oecologia. 98, 167-175.

Grimsdell, J.J.R., Field, C.R., 1976. Grazing patterns of buffaloes in the Rwenzori National Park, Uganda. E. Afr. Wildl. J. 14, 339-344.

Hall-Martin, A.J., 1974. Food selection by Transvaal Lowveld giraffe as determined by analysis of stomach contents. J. S. Afr. Wildl. Manage. Ass. 4(3), 191-202.

Hall-Martin, A.J., 1975. Aspects of the ecology and sociality of the giraffe (Giraffa camelopardalis giraffa) Pub.Univ.Pret.(New Series). 97, 48-56. 
Hall-Martin, A.J. 1976. Dentition and age determination of the giraffe, Giraffa camelopardalis. J. Zool. (Lond.). 180, 263-289.

Hall-Martin, A.J., 1977. Giraffe weight estimation using dissected leg weight and body measurements. J. Wildl. Manage. 41(4), 740-745.

Hall-Martin, A.J., Basson, W.D., 1975. Seasonal chemical composition of the diet of Transvaal Lowveld giraffe. J. S. Afr. Wildl. Manage. Ass. 5(1), 19-21.

Hall-Martin, A.J., von la Chevallerie, M., Skinner, J.D., 1977. Carcass composition of the giraffe, Giraffa camelopardalis giraffa. S. Afr. J. Anim. Sci. 7, 55-64.

Hamilton, W.R. 1978. Fossil giraffes from the Miocene of Africa and a revision of the phylogeny of the Giraffoidea. Phil.Trans.Roy. Soc. B. 283, 165-229.

Hayssen, V., Lacy, R.C., 1985. Basal metabolic rates in mammals: taxonomic differences in the allometry of BMR and body mass. Comp. Biochem. Physiol. A. 81, 741-754.

Hofmann, R.R., 1989. Evolutionary steps of ecophysiological adaptation and diversification of ruminants: a comparative view of their digestive system. Oecologia. 78, 443-457.

Hofmann, R.R., Streich, W.J., Fickel, J., Hummel, J., Clauss, M. 2008. Convergent evolution in feeding types: salivary gland mass differences in wild ruminant species. J. Morph. 269,240-257.

Home, E. 1828. On the peculiarities of the tongue of the Xariffa and on the muscular structure of tongues in general. Lectures on Comparative Anatomy. 5, 244-249.

Hummel, J., Südekum, K-H., Streich, W.J., Clauss, M., 2006. Forage fermentation patterns and their implications for herbivore ingesta retention times. Funct. Ecol. 20, 989-1002.

Illius, A.W., Gordon, I.J., 1992. Modelling the nutritional ecology of ungulate vertebrates: evolution of body size and competitive interactions. Oecologia. 89, 428-434.

Innis, A.C., 1958. The behaviour of the giraffe, Giraffa camelopardalis, in the Eastern Transvaal. Proc. Zool. Soc. (Lond.). 131, 245-278.

Jetz, W., Carbone, C., Fulford, J., Brown, J.H., 2004. The scaling of animal space use. Science. 306, $266-268$. Joly, N., Lavocat, A., 1846. Recherches historiques, zoologiques, anatomiques et palaeontologiques sur la giraffe. Mem. Soc. Sci. Nat. Strasbourg. III, 1-112.

Kay, R.N.B. 1987. Weights of salivary glands in some ruminant animals. J. Zool. (Lond.). 211, 431-436.

Kleiber, M., 1961. The fire of life. Wiley, New York.

Langman, V.A., 1973. Radio-tracking giraffe for ecological studies. J. S. Afr. Wildl. Manage. Ass. 3(2), 75-78. Langman, V.A., Bamford, O.S., Maloiy, G.M.O., 1982. Respiration and metabolism in the giraffe. Resp. Physiol. 50, 141-152.

Lechner, I., Barboza, P., Collins, W.,Günther,D.,Hattendorf, B., Hummel, J., Clauss, M. 2009. No “bypass” in adult ruminants: passage of fluid ingested vs fluid inserted into the rumen in fistulated muskoxen (Ovibos moschatus), reindeer (Rangifer tarandus) and moose (Alces alces). Comp.Biochem.Physiol.A. 154: 151-156. Leuthold, B.M., Leuthold, W., 1972. Food habits of giraffe in Tsavo National Park, Kenya. E. Afr. Wildl. J. 10, 129- 141.

Leuthold, B.M., Leuthold, W., 1978. Ecology of the giraffe in Tsavo East National Park, Kenya. E. Afr. Wildl. J. 16, 1- 20.

Lindstedt, S.L., Miller, B.J., Buskirk, S.W., 1986. Home range, time, and body size in mammals. Ecology. 67(2), 413-418.

Luna, R.S., Duarte, A., Weckerly, F.W., 2012. Rumen-reticulum characteristics, scaling relationships, and ontogeny in white tailed deer (Odocoileus virginianus). Can. J. Zool. 90, 1351-1358.

Maloiy, G.M.O., Clemens, E.T., Kamau, J.M.Z., 1982. Aspects of digestion and in vitro rumen fermentation rate in six species of East African wild ruminants. J. Zool. (Lond.). 197, 345-353.

McNab, B.K., 1963. Bioenergetics and the determination of home range size. Am. Nat. 97,133-140.

McNab, B.K., 2002. The physiological ecology of vertebrates. Cornell University Press, New York.

Mitchell, G., Roberts, D.G., van Sittert, S.J., Skinner, J.D., 2013A. Orbit orientation and eye morphometrics in giraffes (Giraffa camelopardalis). Afr. Zool. 48(2), 333-339.

Mitchell, G., Roberts, D., van Sittert, S., Skinner, J.D. 2013B. Growth patterns and masses of the heads and necks of male and female giraffes. J. Zool. (Lond.). 290, 49-57.

Mitchell, G., Skinner, J.D., 2011. Lung volumes in giraffes, Giraffa camelopardalis. Comp. Biochem. Physiol. A. 158, 72-78.

Mitchell, G., van Sittert, S., Skinner, J.D. 2009. Sexual selection is not the origin of long necks in giraffes. J. Zool. (Lond.). 278, 281-286.

Muller, D.W.H., Codron, D., Meloro, C., Munn, A., Schwarm, A., Hummel, J., Clauss, M., 2013. Assessing the Jarman-Bell principle: scaling of intake, digestibility, retention time and gut fill with body mass in mammalian herbivores. Comp. Biochem. Physiol. A.164, 129-140.

Murie, J., 1872. On the horns, viscera and muscles of the giraffe, with a record of the post-mortem examination of two specimens killed by a fire. Ann. Mag. Nat. Hist. Edinburgh. Ser 4. IX, 177-195. 
Nagy, K.A., 1987. Field metabolic rate and food requirement scaling in mammals and birds. Ecol. Monogr. 57(2), 111-128.

Nagy, K.A., 1994. Field bioenergetics of mammals: what determines field metabolic rates. Austr. J. Zool. 42, 43-53.

Nagy, K.A., 2001. Food requirements of wild animals: predictive equations for free-living mammals, reptiles, and birds. Nutr. Abstr. Rev. B. 71, 21R-32R.

Nagy, K.A., 2005. Field metabolic rate and body size. J. Exp. Biol. 208, 1621-1625.

Owen, R., 1838. Notes on the anatomy of the Nubian giraffe. Trans. Zool. Soc. (Lond.). 2, 217-248.

Owen-Smith, N. 1997. Distinctive features of the nutritional ecology of browsing versus grazing ruminants.

Zeit. Saugetier. 62 (Suppl 2), 176-191.

Patterson, J.L., Goetz, R.H., Doyle, J.T., Warren, J.V., Gauer, O.H., Detweiler, D.K.,Said S.I., Hoernicke, H., McGregor, M., Keen, E.N., Smith, M.H., Hardie E.L., Reynolds, M., Flatt, W.P., Waldo, D.R., 1965.

Cardiorespiratory dynamics in the ox, and giraffe, with comparative observations on man and other mammals. Ann. N.Y. Acad. Sci. 127, 393-413.

Pellew, R.A., 1983A. The giraffe and its food resource in the Serengeti. I. Composition, biomass, and production of available browse. Afr. J. Ecol. 21, 241-267.

Pellew, R.A., 1983B The giraffe and its food resource in the Serengeti. II. Response of the giraffe population to changes in the food supply. Afr. J. Ecol. 21, 269-283.

Pellew, R.A., 1984A. Food consumption and energy budgets of the giraffe. J. App. Ecol. 21,141-159.

Pellew, R.A., 1984B. The feeding ecology of a selective browser, the giraffe (Giraffa camelopardalis tippelskirchi). J. Zool.(Lond). 202, 57-81.

Perez, W., Lima, M., Clauss, M., 2009. Gross anatomy of the intestine in the giraffe (Giraffa camelopardalis). Anat. Histol. Embryol. 38, 432-435.

Perez, W., Michel, V., Hassen, J., Vazquez, N. 2012. Anatomy of the mouth of the Giraffe

(Giraffa camelopardalis rothschildi). Int. J. Morph.30(1), 322-329.

Richiardi, S., 1880. Sull' anatomia della giraffa (Anatomy of the giraffe). Zool. Anz. 3, 92-93.

Robbins, CT., Spalinger, DE., van Hoven, W. 1995. Adaptation of ruminants to browse and grass diets: are anatomical-based browser-grazer interpretations valid? Oecologia. 103,208-213.

Ryan, S.J., Jordaan, W., 2005. Activity patterns of African buffalo Syncerus caffer in the lower Sabie region, Kruger National Park, South Africa. Koedoe. 48(2), 117-124.

Sasaki, M., Endo, H., Kitamura, N., Yamada, J., Yamamoto, M., Arishima, K.., Hayashi, Y. 2001. The structure of the masseter muscle in the giraffe (Giraffa camelopardalis). Anat. Histol. Embryol. 30, 313-319.

Schmidt-Nielsen, K., 1997. Animal Physiology. Cambridge University Press, Cambridge.

Schiviz, A.N., Ruf, T., Kueberr-Heiss, A., Schubert, C., Ahnelt, P.K., 2008. Retinal cone topography of artiodactyl mammals.: influence of body height and habitat. J. Comp. Neurol. 507, 1336-1350.

Singer, R., Bonè, EL. 1960. Modern giraffes and the fossil Giraffids of Africa. Ann. S. Afr. Mus. 45, 375-548.

Solounias, N., Moelleken, SMC. 1993. Dietary adaptation of some extinct ruminants determined by premaxillary shape. J. Mammal. 74, 1059-1071.

Stahl, W.R., 1967. Scaling of respiratory variables in mammals. J. App. Physiol. 22(3), 453-460.

Tucker, M.A., Ord, T.J., Rogers, T.L., 2014. Evolutionary predictors of mammalian home range size: body mass, diet and the environment. Global Ecol. Biogeogr. 23, 1105-1114.

VanderWaal, K.L., Wang, H., McCowan, B., Fushing, H., Isbell, L.A., 2014. Multilevel social organization and space use in reticulated giraffe (Giraffa camelopardalis). Behav. Ecol. 25, 17-26.

Van Soest P.J. 1996. Allometry and ecology of feeding behavior and digestive capacity in herbivores: a review. Zoo Biol. 15, 455-479.

Weckerly, F.W., 2010. Allometric scaling of rumen-reticulum capacity in white-tailed deer. J. Zool. (Lond.). 280, 41-48.

White. C.R., Seymour, R.S., 2002. Mammalian basal metabolic rate is proportional to body mass ${ }^{2 / 3}$. Proc. Nat. Acad. Sci. 100, 4046-4049.

Woodall, P.F., Skinner, J.D. 1993. Dimensions of the intestines, diet and faecal water loss in some African antelope. Journal of Zoology (London). 229:457-471.

Woolnough, A.P., du Toit, J.T., 2001. Vertical zonation of browse quality in tree canopies exposed to a sizestructures guild of African browsing ungulates. Oecologia. 129, 585-590.

Young, T.P., Isbell, L.A., 1991. Sex differences in giraffe feeding ecology: energetic and social constraints. Ethology. 87, 79-89. 


\section{Tables}

Table 1A. Allometric equations describing the weights $(\mathrm{kg})$ of components of the gastro-intestinal tract (GIT) in 32 Zimbabwean giraffes of mean body mass $859.1 \mathrm{~kg}$

\begin{tabular}{|c|c|c|c|c|c|}
\hline & $\begin{array}{l}\text { Allometric } \\
\text { Equation }\end{array}$ & CI(exp) & R2 & $\mathrm{P}\left(\mathrm{R}^{2}\right)$ & $\begin{array}{cc} & 888 \\
\text { mean } \pm \text { SD } & 889 \\
& 890 \\
\end{array}$ \\
\hline $\begin{array}{l}\text { Rumen-complex } \\
\text { mass (kg) }\end{array}$ & $1.17^{*} \mathrm{Mb}^{\wedge} .64$ & $.36-.92$ & .5352 & $<.05$ & $87.9 \pm 25.891$ \\
\hline $\begin{array}{l}\text { Small Intestine } \\
(\mathrm{kg})^{*}\end{array}$ & $.035^{*} \mathrm{Mb}^{\wedge} .92$ & $.70-1.13$ & .8057 & $<.05$ & $\begin{array}{r}16.6 \pm 5.7892 \\
893\end{array}$ \\
\hline $\begin{array}{l}\text { Large Intestine } \\
(\mathrm{kg})^{*}\end{array}$ & $.075^{*} \mathrm{Mb}^{\wedge} .92$ & $. .70-1.13$ & ..8057 & $<.05$ & $\begin{array}{r}35.8 \pm 12.894 \\
895\end{array}$ \\
\hline $\begin{array}{l}\text { Total Intestine } \\
\text { mass }(\mathrm{kg})\end{array}$ & $.11 * \mathrm{Mb}^{\wedge} .92$ & $.70-1.13$ & .8057 & $<.05$ & $\begin{array}{r}52.4 \pm 17.896 \\
897\end{array}$ \\
\hline $\begin{array}{l}\text { Rumen-complex } \\
+ \text { intestine mass } \\
(\mathrm{kg})\end{array}$ & $.69 * \mathrm{Mb}^{\wedge} .79$ & $.63-.97$ & .7740 & $<.05$ & $\begin{array}{r}148.2 \pm 44.898 \\
899 \\
\end{array}$ \\
\hline
\end{tabular}

Table 1B. The length of intestines (metres) in giraffes

\begin{tabular}{|c|c|c|c|c|c|c|c|}
\hline Reference & $\begin{array}{l}\text { Age } \\
\text { (years) }\end{array}$ & $\begin{array}{l}\text { Body mass } \\
(\mathrm{kg})\end{array}$ & Sex & $\begin{array}{l}\text { Small } \\
\text { intestine } \\
\text { (metres) }\end{array}$ & $\begin{array}{l}\text { Large } \\
\text { Intestine } \\
\text { (metres) }\end{array}$ & $\begin{array}{l}\text { Caecum } \\
\text { (metres) }\end{array}$ & $\begin{array}{l}\text { Total } \\
\text { Intestine } \\
\text { (metres) }\end{array}$ \\
\hline Owen 1838 & $c a 3$ & Not known & $\mathrm{F}$ & 27.7 & 13.2 & .67 & 40.9 \\
\hline “" & ca 3 & “" & $M$ & 26.8 & 13.1 & .61 & 39.9 \\
\hline “6 & ca 3 & “6 & $\mathrm{M}$ & 25.0 & 12.2 & .61 & 37.2 \\
\hline $\begin{array}{l}\text { Joly \& } \\
\text { Lavocat } \\
1846\end{array}$ & young & “" & $\mathrm{F}$ & & & & 62.3 \\
\hline Crisp 1864A & 18 & 815 & $\mathrm{~F}$ & & & & 77.4 \\
\hline “" & 4 & 815 & $\mathrm{M}$ & & & & 63.7 \\
\hline “6 & .17 & 153 & $\mathrm{~F}$ & & & & 32.6 \\
\hline Crisp 1864B & .58 & 153 & $\mathrm{M}$ & 27.4 & 10.1 & & 37.5 \\
\hline Crisp 1866 & 12 & Not known & $\mathrm{F}$ & 39.5 & 25.2 & & 64.7 \\
\hline Murie 1872 & .17 & “" & $\mathrm{M}$ & 24.7 & 5.8 & .48 & 31.2 \\
\hline “" & 11.6 & “" & $\mathrm{F}$ & 39.2 & 24.9 & .53 & 64.8 \\
\hline “" & 21.3 & “" & $\mathrm{M}$ & 39.8 & 27.7 & .46 & 68.1 \\
\hline $\begin{array}{l}\text { Richiardi } \\
1880\end{array}$ & old & "6 & $\mathrm{M}$ & 52.2 & 24.2 & .72 & 76.4 \\
\hline $\begin{array}{l}\text { Beddard } \\
1902\end{array}$ & old & “" & $\mathrm{M}$ & 59.7 & 22.9 & .76 & 83.2 \\
\hline $\begin{array}{l}\text { Perez et al, } \\
2009\end{array}$ & 2.1 & 754 & $\mathrm{M}$ & 27.8 & 24.3 & .44 & 52.5 \\
\hline “" & 17 & 800 & $\mathrm{~F}$ & 47.4 & 23.8 & .96 & 72.2 \\
\hline Mean \pm s.d. & & & & $36.4 \pm 11.8$ & $18.9 \pm 7.5$ & $0.62 \pm 0.16$ & $55.7 \pm 17.9$ \\
\hline
\end{tabular}


Table 1C. Allometry of rumen content mass and intestine length and mucosal surface area in wild African ruminants

\begin{tabular}{|llllll|}
\hline & Type & Allometric Equation & R2 & CI(exp) & $\begin{array}{l}\text { Predicted } \\
\text { Giraffe } \\
\text { mean } \pm \text { SD }\end{array}$ \\
\hline $\begin{array}{l}\text { Rumen } \\
\text { content mass } \\
(\mathrm{kg})\end{array}$ & $\mathrm{G}$ & $.064^{*} \mathrm{Mb}^{\wedge} 1.16$ & .9935 & $1.08-1.24$ & $144.1 \pm 72.9$ \\
\hline $\begin{array}{l}\text { Small intestine } \\
\text { length }(\mathrm{m})\end{array}$ & $\mathrm{G}$ & $.91 * \mathrm{Mb}^{\wedge} .61$ & .7935 & $.30-.93$ & $50.8 \pm 15.1$ \\
\hline $\begin{array}{l}\text { Large intestine } \\
\text { length }(\mathrm{m})\end{array}$ & $\mathrm{G}$ & $1.5^{*} \mathrm{Mb}^{\wedge} .33$ & .4660 & $-.02-1.07$ & $13.0 \pm 2.2$ \\
\hline $\begin{array}{l}\text { Small intestine } \\
\text { area }\left(\mathrm{m}^{2}\right)\end{array}$ & $\mathrm{G}$ & $.073^{*} \mathrm{~L}^{\wedge} 1.25$ & .8960 & $.82-1.7$ & $10.0 \pm 3.6$ \\
\hline $\begin{array}{l}\text { Large intestine } \\
\text { area }\left(\mathrm{m}^{2}\right)\end{array}$ & $\mathrm{G}$ & $.51^{*} \mathrm{~L}^{\wedge} 1.13$ & .6657 & $.33-1.9$ & $9.3 \pm 1.8$ \\
\hline $\begin{array}{l}\text { Small intestine } \\
\text { length }(\mathrm{m})\end{array}$ & $\mathrm{IM} / \mathrm{B}$ & $2.5^{*} \mathrm{Mb}^{\wedge} .42$ & .9271 & $.30-.54$ & $39.4 \pm 8.5$ \\
\hline $\begin{array}{l}\text { Large intestine } \\
\text { length }(\mathrm{m})\end{array}$ & $\mathrm{IM} / \mathrm{B}$ & $.87 * \mathrm{Mb}^{\wedge} .49$ & .9493 & $.38-.60$ & $21.8 \pm 5.4$ \\
\hline $\begin{array}{l}\text { Small intestine } \\
\text { area }\left(\mathrm{m}^{2}\right)\end{array}$ & $\mathrm{IM} / \mathrm{B}$ & $.022^{*} \mathrm{~L}^{\wedge} 1.7$ & .9628 & $1.4-2.0$ & $11.7 \pm 4.0$ \\
\hline $\begin{array}{l}\text { Large intestine } \\
\text { area }\left(\mathrm{m}^{2}\right)\end{array}$ & $\mathrm{IM} / \mathrm{B}$ & $.25 * \mathrm{~L}^{\wedge} 1.45$ & .9845 & $1.3-1.6$ & $22.3 \pm 7.6$ \\
\hline
\end{tabular}

Data from Giesecke \& van Gylswyk, 1975; Demment, 1982; Maloiy et al, 1982; Woodall \& Skinner 1993.

Table 2A. Parotid gland mass and secretion rate in 9 giraffes.

\begin{tabular}{|c|c|c|c|c|c|c|}
\hline $\begin{array}{l}\text { Body } \\
\text { mass } \\
(\mathrm{kg})\end{array}$ & Gender & $\begin{array}{c}\text { Parotid } \\
\text { gland mass } \\
\text { (grams) }\end{array}$ & $\begin{array}{c}\text { Parotid } \\
\text { mass as } \% \\
\mathrm{Mb}\end{array}$ & $\begin{array}{c}\text { DM intake } \\
\text { (kg/day) }\end{array}$ & $\begin{array}{c}\text { Saliva } \\
(\mathrm{ml} / \mathrm{g} / \mathrm{min})\end{array}$ & $\begin{array}{c}\text { Saliva・• } \\
(\mathrm{ml} / \mathrm{g} / \mathrm{min})\end{array}$ \\
\hline 181 & $\mathrm{M}$ & 90 & 0.050 & 8.0 & 1.0 & 1.2 \\
\hline 227 & $\bar{F}$ & 74 & 0.033 & 9.4 & 0.8 & 1.0 \\
\hline 602 & $\mathrm{M}$ & 162 & 0.027 & 19.4 & 1.1 & 2.2 \\
\hline 727 & $\mathrm{~F}$ & 258 & 0.035 & 22.3 & 1.2 & 3.4 \\
\hline 770 & $\mathrm{M}$ & 340 & 0.044 & 23.3 & 1.0 & 4.5 \\
\hline 801 & $\mathrm{~F}$ & 288 & 0.036 & 23.9 & 1.4 & 3.8 \\
\hline 813 & $\mathrm{M}$ & 242 & 0.030 & 24.2 & 1.0 & 3.2 \\
\hline 1110 & $\mathrm{M}$ & 272 & 0.025 & 30.5 & 0.9 & 3.6 \\
\hline 1396 & $M$ & 422 & 0.030 & 36.1 & 1.3 & 5.6 \\
\hline 736 & & & $0.034 \pm 0.01$ & & $1.1 \pm 0.2$ & $3.2 \pm 1.5$ \\
\hline
\end{tabular}

- Robbins et al 1995; ••Kay 1987(see text); expressed as ml saliva/gram gland mass per minute 
Table 2B. Masseter, mandible, and tongue mass, and tongue length in 9 giraffes.

\begin{tabular}{|c|c|c|c|c|c|c|c|c|}
\hline $\begin{array}{c}\text { Body } \\
\text { mass } \\
(\mathrm{kg})\end{array}$ & Gender & $\begin{array}{c}\text { Masseter } \\
\text { muscles } \\
\text { mass } \\
(\mathrm{kg})\end{array}$ & $\begin{array}{c}\text { Masseter } \\
\text { mass as } \\
\% \mathrm{Mb}\end{array}$ & $\begin{array}{c}\text { Mandibles } \\
\text { mass } \\
(\mathrm{kg})\end{array}$ & $\begin{array}{c}\text { Mandibles } \\
\text { Mass as } \\
\% \mathrm{Mb}\end{array}$ & $\begin{array}{c}\text { Masseter: } \\
\text { Mandible } \\
\text { ratio }\end{array}$ & $\begin{array}{c}\text { Tongue } \\
\text { length } \\
(\mathrm{cm})\end{array}$ & $\begin{array}{c}\text { To9gae } \\
\text { mo4s } \\
(\text { gq) } \\
043\end{array}$ \\
\hline 181 & $\mathrm{M}$ & 0.240 & 0.13 & 0.338 & 0.19 & 0.71 & 40 & 0.438 \\
\hline 227 & $\mathrm{~F}$ & 0.264 & 0.12 & 0.396 & 0.17 & 0.67 & 42 & 0.502 \\
\hline 602 & $\mathrm{M}$ & 0.848 & 0.14 & 1.254 & 0.21 & 0.68 & 63 & 1. $15 \overline{2}$ \\
\hline 727 & $\mathrm{~F}$ & 1.056 & 0.15 & 1.274 & 0.18 & 0.83 & 66 & 1.278 \\
\hline 770 & $\mathrm{M}$ & 1.132 & 0.15 & 1.634 & 0.21 & 0.69 & 68 & 1.944 \\
\hline 801 & $\mathrm{~F}$ & 1.304 & 0.16 & 1.406 & 0.18 & 0.93 & 64 & 1.108 \\
\hline 813 & $\mathrm{M}$ & 1.184 & 0.15 & 1.420 & 0.17 & 0.83 & 63 & 1.949 \\
\hline 1110 & M & 1.322 & 0.12 & 1.672 & 0.15 & 0.79 & 71 & 1.924 \\
\hline 1396 & $\mathrm{M}$ & 1.642 & 0.12 & 1.706 & 0.12 & 0.96 & 71 & 1.824 \\
\hline 736 & & & $0.14 \pm 0.02$ & & $0.18 \pm 0.03$ & $0.79 \pm 0.11$ & & 952 \\
\hline
\end{tabular}

Table 3. Parotid and mandibular gland mass in African browsers from Hofmann et al, 2008

\begin{tabular}{|c|c|c|c|c|c|c|}
\hline Species & $\begin{array}{c}\text { Grass } \\
(\%)\end{array}$ & $\begin{array}{l}\mathrm{Mb} \\
(\mathrm{kg})\end{array}$ & $\begin{array}{c}\text { Parotid } \\
\text { as } \% \mathrm{Mb}\end{array}$ & $\begin{array}{c}\text { Mandibular. } \\
\text { as } \% \mathrm{Mb}\end{array}$ & $\begin{array}{l}\text { Buccal } \\
\text { as } \% \mathrm{Mb}\end{array}$ & $\begin{array}{c}\text { Sublingual } \\
\text { as } \% \mathrm{Mb}\end{array}$ \\
\hline Suni & 0 & 3.7 & .22 & .16 & .03 & .03 \\
\hline Blue duiker & 1 & 4 & .18 & .12 & .04 & \\
\hline Dik-dik & 5 & 4.4 & .28 & .10 & .03 & .03 \\
\hline Red Duiker & 0 & 8.3 & .19 & .13 & .04 & \\
\hline Steenbok & 10 & 10.8 & .16 & .06 & .02 & .01 \\
\hline $\begin{array}{l}\text { Common } \\
\text { Duiker }\end{array}$ & 5 & 13 & .29 & .16 & .03 & .02 \\
\hline Gerenuk & 0 & 33.5 & .18 & $.10 *$ & & \\
\hline Bushbuck & 10 & 45.3 & .13 & .10 & & \\
\hline Lesser kudu & 10 & 46.5 & .11 & .10 & .02 & \\
\hline $\begin{array}{l}\text { Greater } \\
\text { kudu }\end{array}$ & 5 & 102.3 & .11 & .10 & .02 & .01 \\
\hline & $\begin{array}{c}4.6 \\
\pm 4.3 \\
\end{array}$ & & $\begin{array}{c}0.18 \\
\pm 0.06 \\
\end{array}$ & $\begin{array}{c}0.11 \\
\pm 0.03 \\
\end{array}$ & $\begin{array}{c}0.03 \\
\pm 0.01 \\
\end{array}$ & $\begin{array}{c}0.02 \\
\pm 0.01 \\
\end{array}$ \\
\hline Okapi & 0 & 231 & .07 & & & \\
\hline Giraffe & 0 & 515 & .06 & $.07 \bullet \bullet$ & $.02 \bullet \bullet$ & $.01 \bullet \bullet$ \\
\hline Giraffe••• & 0 & 736 & .034 & & & \\
\hline & 0 & & $\begin{array}{c}0.05 \\
\pm 0.02\end{array}$ & & & \\
\hline
\end{tabular}


Table 4 Energy balance in giraffes

\begin{tabular}{|c|c|c|c|c|c|c|}
\hline & $\begin{array}{l}\text { Allometric } \\
\text { equation }\end{array}$ & $\mathrm{R} 2$ & $\mathrm{CI}(\exp )$ & $\begin{array}{l}\text { Range in } \\
\text { giraffes of } \\
\mathrm{Mb}=289-1441 \\
\mathrm{~kg}\end{array}$ & Mean \pm sd & Reference \\
\hline $\begin{array}{c}\text { RMR } \\
\text { (kj/day) }\end{array}$ & $279.4 * \mathrm{Mb}^{\wedge} .77$ & 1.000 & & $21933-75578$ & $50174 \pm 13864$ & $\begin{array}{l}\text { Stahl, 1967; } \\
\text { Hayssen \& } \\
\text { Lacy, 1988; } \\
\text { Schmidt- } \\
\text { Nielsen, } 1997\end{array}$ \\
\hline $\begin{array}{l}\text { FMR } \\
\text { (kj/day) }\end{array}$ & $862.0 * \mathrm{Mb}^{\wedge} .741$ & 1.000 & & $57415-188832$ & $127146 \pm 33930$ & $\begin{array}{l}\text { Nagy, 1994; } \\
\text { 2005; McNab, } \\
\text { 2002; Calder, } \\
1996 .\end{array}$ \\
\hline FMR (watts) & $9.97 * \mathrm{Mb}^{\wedge} .741$ & 1.000 & & $664-2184$ & $1472 \pm 393$ & \\
\hline $\begin{array}{l}\text { Rumen } \\
\text { Fermentation } \\
\text { (kj/day) } \\
\end{array}$ & $601.5^{*} \mathrm{Mb}^{\wedge} .64$ & .9033 & $.59-.70$ & $14887-64171$ & $42203 \pm 14283$ & $\begin{array}{l}\text { Maloiy et al, } \\
\text { 1982; Clemens } \\
\text { \& Maloiy, } 1983\end{array}$ \\
\hline $\begin{array}{l}\text { Hind gut } \\
\text { Fermentation } \\
\text { (kj/day) }\end{array}$ & $53.9^{*} \mathrm{Mb}^{\wedge} .92$ & .9642 & $.87-.96$ & $5177-41338$ & $23386 \pm 10042$ & “" \\
\hline $\begin{array}{l}\text { Total } \\
\text { Fermentation } \\
\text { (kj/day) }\end{array}$ & $513.5^{*} \mathrm{Mb}^{\wedge} .73$ & .9535 & $.69-.78$ & $20065-105509$ & $65589 \pm 23838$ & \\
\hline $\begin{array}{l}\text { Fermentation } \\
\text { : FMR }(\%)\end{array}$ & $117.1 * \mathrm{Mb}^{\wedge}-.09$ & .5434 & $\begin{array}{l}-0.11 \text { to } \\
-0.07\end{array}$ & $74.2-60.8$ & $65.4 \pm 4.6$ & \\
\hline $\begin{array}{l}\text { Digestion: } \\
\text { FMR }(\%)\end{array}$ & $10.5^{*} \mathrm{Mb}^{\wedge} .18$ & .5806 & $.14-.22$ & $25.8-39.2$ & $34.6 \pm 4.6$ & \\
\hline $\begin{array}{l}\text { Energy } \\
\text { deficit } \\
(\mathrm{kj} / \mathrm{day})\end{array}$ & $360.6^{*} \mathrm{Mb}^{\wedge} .74$ & .9228 & $.69-.80$ & $14729-83360$ & $49806 \pm 18643$ & $\begin{array}{l}\text { FMR-Total } \\
\text { Fermentation } \\
\text { Energy }\end{array}$ \\
\hline $\begin{array}{l}\text { Energy } \\
\text { deficit } \\
(\mathrm{kg} / \text { day })\end{array}$ & $.018^{*} \mathrm{Mb}^{\wedge} .74$ &. .9228 & $.69-.80$ & $0.74-4.2$ & $2.5 \pm 0.9$ & $\begin{array}{l}\text { Energy deficit } \\
\div 20 \mathrm{kj} / \text { gram }\end{array}$ \\
\hline
\end{tabular}

RMR $=$ Resting metabolic rate; FMR $=$ Field metabolic rate. 
Table 5 Food intake and Home Range

\begin{tabular}{lllll}
\hline & Allometric equation & $\begin{array}{l}\text { Range in giraffes of } \\
\mathrm{Mb}=289-1441 \mathrm{~kg}\end{array}$ & $\begin{array}{l}\text { Mean } \pm \\
\text { s.d }\end{array}$ & Reference \\
\hline $\begin{array}{l}\text { Mean food intake } \\
(\mathrm{kg} \mathrm{DM} / \text { day })^{*}\end{array}$ & $.103 * \mathrm{Mb}^{\wedge} .74$ & $6.8-22.5$ & $15.1 \pm 4.0$ & $\begin{array}{l}\text { Hall-Martin \&Basson, 1975; } \\
\text { Pellew 1984B }\end{array}$ \\
\hline & & & & \\
\hline $\begin{array}{l}\text { Minimum Home } \\
\text { range }\left(\mathrm{km}^{2}\right)^{*}\end{array}$ & $.054^{*} \mathrm{Mb}^{\wedge} .74$ & $2.2-11.8$. & $7.2 \pm 2.5$ & \\
\hline $\begin{array}{l}\text { Predicted Home } \\
\text { range }\left(\mathrm{km}^{2}\right)\end{array}$ & $.014 * \mathrm{Mb}^{\wedge} 1.27$ & $8.2-150.5$ & $68.9 \pm 37.8$ & $\begin{array}{l}\text { McNab, 1963; Lindstedt et al } \\
1986 ; \text { du Toit, 1990C; Jetz et } \\
\text { al. 2004; Tucker et al, 2014. }\end{array}$ \\
\hline
\end{tabular}

\section{Figures}

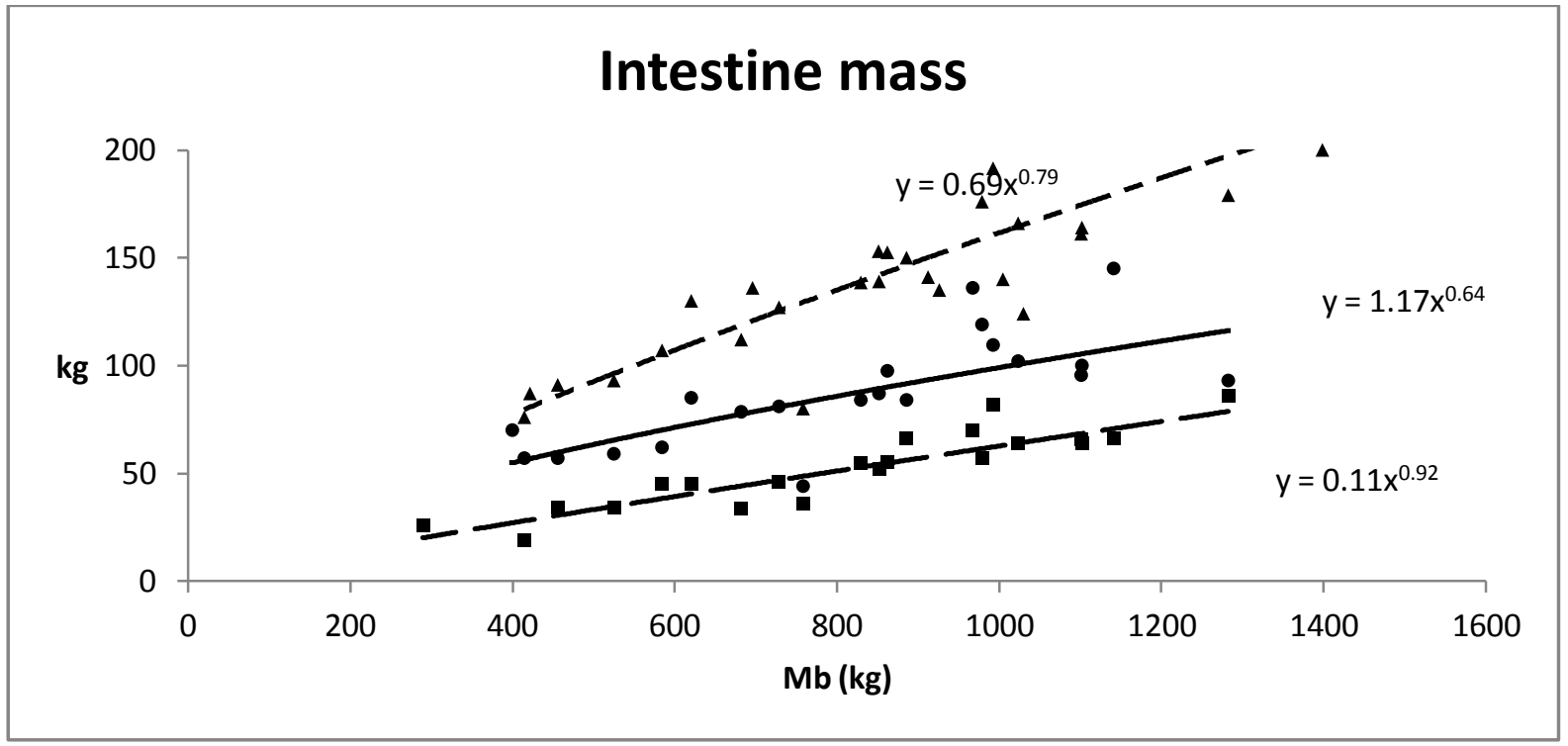

Fig 1. Relationships between body mass and combined intestine mass ( $\boldsymbol{\Delta}$, rumen-complex ( $\bullet$ ), and GIT (ム) in 32 wild giraffes 


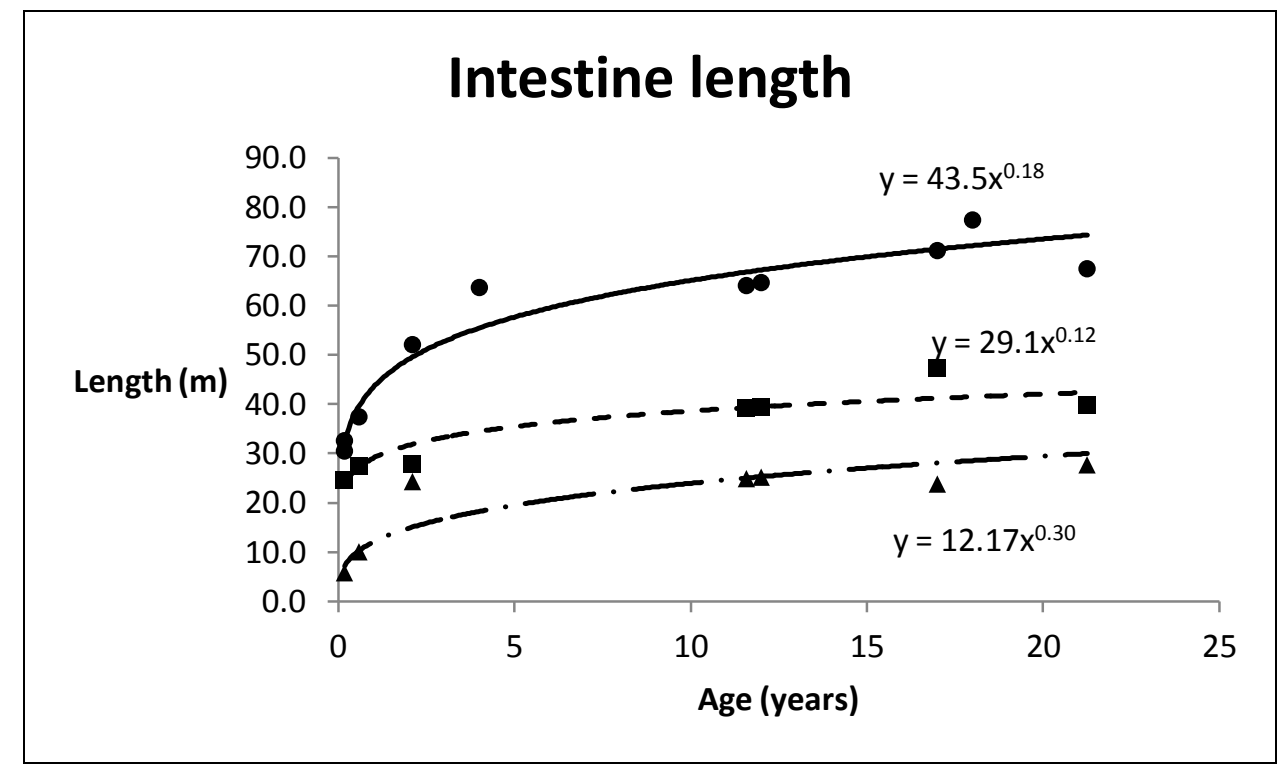

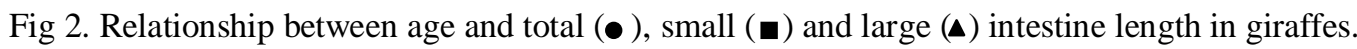

